\title{
Hydrogeology of Eastern Niger Delta: A Review
}

\author{
T. K. S. Abam¹, H. O. Nwankwoala² \\ ${ }^{1}$ Institute of Geosciences and Space Technology, Rivers State University, Port Harcourt, Nigeria \\ ${ }^{2}$ Department of Geology, Faculty of Science, University of Port Harcourt, Port Harcourt, Nigeria \\ Email: groundscan@gmail.com
}

How to cite this paper: Abam, T.K.S. and Nwankwoala, H.O. (2020) Hydrogeology of Eastern Niger Delta: A Review. Journal of Water Resource and Protection, 12, 741-777. https://doi.org/10.4236/jwarp.2020.129045

Received: July 1, 2020

Accepted: September 18, 2020

Published: September 21, 2020

Copyright (C) 2020 by author(s) and Scientific Research Publishing Inc. This work is licensed under the Creative Commons Attribution International License (CC BY 4.0).

http://creativecommons.org/licenses/by/4.0/ (c) (i) Open Access

\begin{abstract}
This paper characterizes the aquifer system of the Niger Delta for sustainable development of the groundwater resource. The heavy-dependence on groundwater in the region and the fears of its unsustainability triggered by the weak regulations, pollution, increasing user population and industrialization coupled with the present limited knowledge of the true geological condition prevailing within the groundwater domain of the Niger Delta are the considerations that compelled this review study. The hydraulic properties of the region's aquifers are discussed. The Niger Delta is characterized by a complex multilayered aquifer system hosted in the Benin Formation with the main body of fresh water, with increasing occurrence of intercalating clay units towards the coast. Lithological analysis indicates the prevalence of unconsolidated sand and sandy gravels in the aquiferous horizons, presenting them as pervious and prolific aquifers. Reported hydrochemical data gathered from wells drilled suggest that the quality of groundwater in the Niger Delta is considered generally very good and compares favorably with WHO standards for drinking water. However, relatively high iron/manganese and chloride values are localized in time and space. In the coastal areas however, seawater intrusion has been identified as one of the major influences on hydrochemistry of groundwater in the shallow unconfined aquifers. Regional groundwater flow direction is from north to south. Changes in groundwater flow directions which occur at some places generally serve localized discharge areas. The resultant flow path eventually joins and feeds the major regional north-south flow direction. The increasing pressure on groundwater, the need for urgent attention and the absence of strong institutions and regulations have made the management of groundwater resources in the region a difficult task. Therefore, future ground water resources development in the Niger Delta requires adequate observational data, investments in infrastructure and an integrated management approach to ensure optimal basin-wide benefits.
\end{abstract}




\section{Keywords}

Hydrogeology, Groundwater Quality, Saline Water Intrusion, Aquifer, Water Table, Niger Delta

\section{Introduction}

Most of the Niger Delta relies on groundwater for both domestic and industrial uses. According to JICA (2014); there were around 65,000 boreholes in Nigeria extracting an estimated total of $6,340,000 \mathrm{~m}^{3} /$ day in 2013 . Before the 1970 's the major cities in the region were served by well planned, relatively deep boreholes whose water was widely reticulated to individual homes and factories. With increasing user population, urbanization and industrialization, coupled with funding constraints governments' capacity to sustain reticulated supply of water was jeopardized. The failure of government to meet the water supply needs of the population resulted in individual's taking responsibility for their water supply needs.

A 1996 survey by the Ministry of Water Resources found only 63\% of Nigerian boreholes was in working order, with many out of action due to pump failure [1]. Borehole failures became common with increased number of individual boreholes drilling. The Ministry of Water Resources [2] ascribes these failures to the absence of management structure for boreholes: most are meant to be managed by communities, but only around one fifth of rural communities were identified as having borehole management organizations, so that actual management, including restoring non-operational boreholes, is not optimum. The problem of frequent abortive boreholes in the area cannot be blamed on the inability of the aquifer to yield enough water, but on the incompetence of the drilling contractors [3]. The unprecedented demand for freshwater associated with high population growth and increased living standards has resulted in highly elevated groundwater drilling activities, which is now creating some concern over the sustainability of the resource for the future.

Groundwater is increasingly becoming a sensitive subject because of the increasing pressure from pollution on the resource. Firstly, there is the general perception that the alternative rain water is polluted by gaseous emissions released by wide spread oil production and processing facilities in the region. Secondly, there is presently no control over who can abstract water and how much an individual or facility can take. There is also the issue of groundwater vulnerability to contamination from spilled hydrocarbon and leachates arising from widely practiced and unregulated surface disposal of wastes. The threat to groundwater quality is exacerbated by a combination of factors, including high groundwater table and widespread unconsolidated permeable superficial alluvial deltaic soils, proximity of major abstracting industries to the coast and the poor record of effluent quality management of major industrial complexes. The pre- 
valence of these, mostly interrelated issues, are now instigating fears as to the future of groundwater in the region.

The second motivating reason for this review study is that several previous studies of the groundwater in the region have been localized [4] [5] [6] [7] and therefore do not offer comprehensive and holistic understanding of issues such as long-term quality and sustainability in the face of climate change and industrialization. There is therefore no doubt that a better understanding of the regional hydrogeology is essential in the overall sustainable management of the region's groundwater resources.

\section{Geology of the Niger Delta}

The geology of the Niger Delta has been studied by several geoscientists [8]-[18]. There is agreement amongst these that the Niger Delta is underlain by three principal formations, namely: Akata, Agbada and Benin Formations (Table 1). The Akata Formation, which is predominantly shale and clay and the Agbada Formation which is generally fluviatile and fluviomarine are primarily of interest to the hydrocarbon industry.

The depositional pattern which accompanied sedimentation during the formation of the delta, gave rise to structural traps (growth faults and roll-over anticlines) in the Agbada Formation, which facilitated the accumulation of petroleum in the reservoirs of the Niger Delta. The Agbada Formation while suitable for petroleum accumulation is considered too deep to be of interest for groundwater abstraction. Together, Akata and Agbada formations provide hydrocarbon source rock and reservoir and account for nearly all the hydrocarbon discoveries in the Nigeria. The Benin Formation on the other hand which occurs at shallower horizons consists of continental deposit of sand and gravel [19] and is therefore of greater significance to the groundwater and civil construction sectors. It is now well known that the Benin Formation (Miocene to Recent) posses' excellent water yielding properties even at great depths [20] [21]. Well cuttings from the logs of oil wells spread across the Niger delta, reveal that the Benin Formation is laterally extensive and extends to depths of $2000 \mathrm{~m}$ in places. The

Table 1. Geological Units of the Niger Delta as summarized by Short and Stauble [9].

\begin{tabular}{lll}
\hline Age & Geological Unit & Lithology \\
\hline Quaternary & -Alluvium (general) freshwater & -Gravel, sand, clay, silt, \\
& back swamp meander belt. & \\
& -Mangrove and salt water & -Silt, clay and sand \\
& -Back Swamps & -Medium fine sand and silt \\
& -Active/Abandoned Beach ridges & -Fine sand, silt and clay \\
Miocene & Benin Formation (Coastal plain & -Coarse to medium grain sand with subordinate silt \\
& sand) & and clay lenses, fluviatile marine \\
Eocene & Agbada Formation & -Mixture of sand, clay and silt, fluviatile marine \\
\hline
\end{tabular}


granular composition of Benin Formation presents it as a veritable construction aggregate, besides serving as competent layer to support most piled foundations within depths of civil engineering significance.

However, due to the continuing evolution of the delta, the three major formations have now been overlain by various types of Quaternary and Cenozoic deposits (Figure 1). The Cenozoic succession of recent Niger Delta consists of a continental Upper Deltaic plains made up continental alluvial plains, braided streams and meander Beds. The sediments here are largely unconsolidated sands, feldspar, limonite coated sand grains silt and clay deposited in fresh water beach swamps. Deposition of the aquifer materials is thought to have occurred in alluvial fan, fluvial channel, tidal channel, intertidal flat, beach, and related microenvironments [20].

According to Nwankoala and Ngah the influence of geology on the groundwater resources of the Niger Delta constitutes the most important factor besides

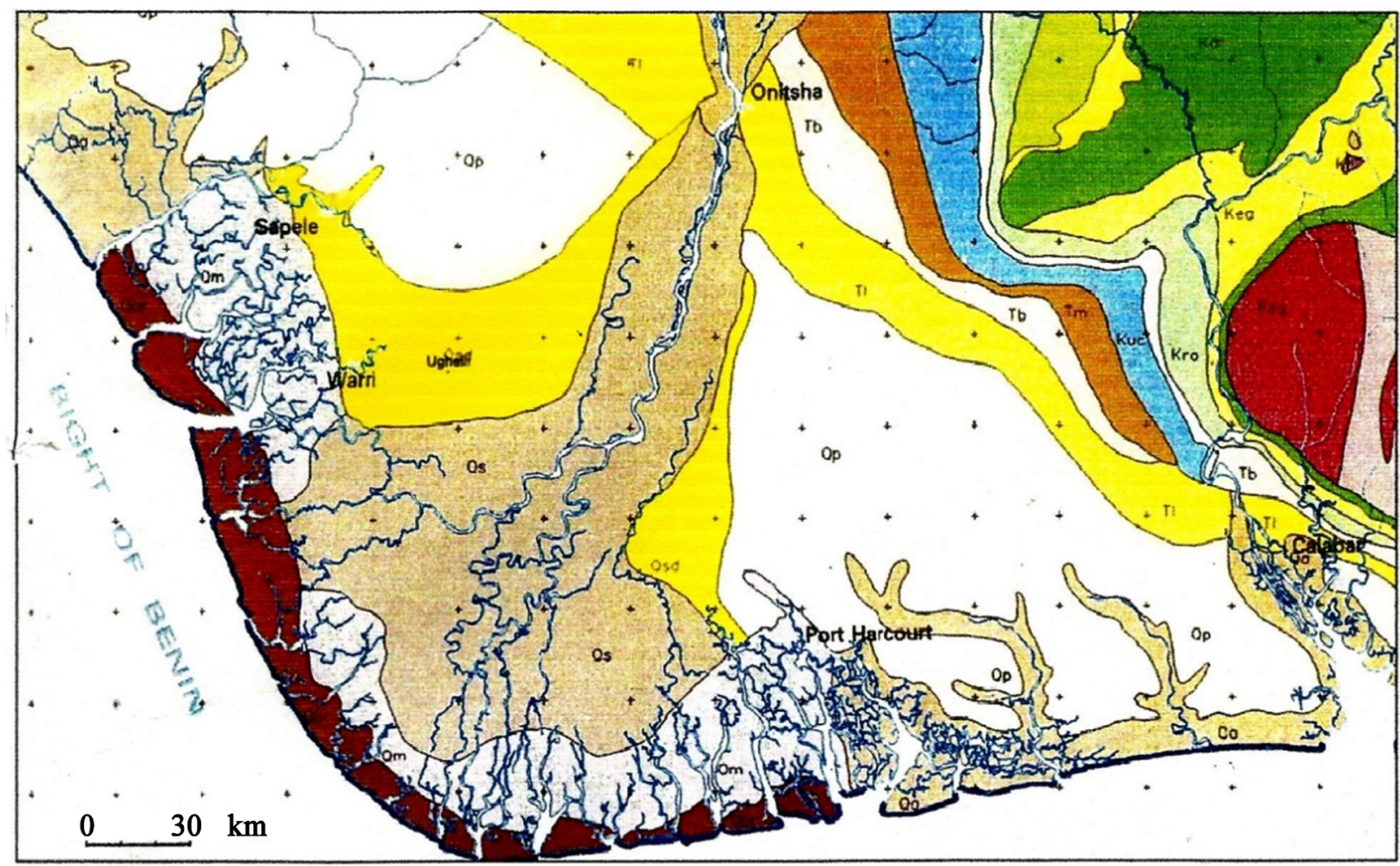

QUATERNARY

Meander belt, Backswamps Qa Alluvium

Freshwater swamps

Mangrove swamps

Abandoned beach ridges

Sombreiro deltaic plain

Coastal plains sands
Qs Sands, gravels and clays

Qm Sands, clays and mangrove swamps

Qbr Sands and pebbles

Qsd Sands, clays and mangrove swamps

Qp Sands and clays
TERTIARY

Lignite formation $\mathrm{Ti}$ Clays, sandstone, lignite and shales Bende Ameki group $\mathrm{Tb}$ Clays, clayey sand and shales Imo clay-shale group Tm Clays and shales with limestone

Figure 1. Geological map of the Niger Delta [after 18]. 
that of climate in the region [21]. Geology has been observed to be responsible for the complex groundwater distribution, extractability and quality in the Niger Delta. Unfortunately, the current state of knowledge of the true geological condition of the groundwater bearing domain of the Niger Delta is limited.

The progress in the improved understanding of the geology of the delta has been due largely to the investments and data yields of the oil industry. Understandably therefore, researches in the delta have been skewed towards petroleum geology. This explains why the present knowledge of the Benin Formation is limited, compared with that of the Akata and Agbada Formations.

\section{The Structure of Benin Formation}

The Benin Formation serves as the groundwater reservoir in the region. The main body of groundwater in the Niger Delta is contained in the extensive sand and gravel layers which are interspersed with shale and clay layers within the formation. Thus, a meaningful study of the region's groundwater needs an understanding of the sedimentation pattern as well as stratification, both of which determine not only the aquifer type distribution but also the quantity and quality of water in the region.

Previous works [6] [22] and [23] indicate that the Benin Formation is differentiated into three main zones, namely; 1) a northern bordering zone consisting of shallow aquifers of predominantly continental deposit, 2) a transition zone of intermixing marine and continental materials and 3) a coastal zone of predominantly marine deposits. Distinct spatial trends in aquifer properties have also been observed following this division.

Akpokodje et al., [24] summarized the hydrostratigraphic units of the Benin Formation as consisting of four well defined aquifers in the upper $305 \mathrm{~m}$ that vary in thickness. The aquifers vary from unconfined conditions at the surface through semi-confined to confined conditions at depth. The aquifers are separated by highly discontinuous layers of shales, giving a picture of an interval that consists of a complex, non-uniform, discontinuous and heterogeneous aquifer system. This is also evident from a Fence diagram of boreholes within a $25 \mathrm{~km}^{2}$ area around PortHarcourt (Figure 2).

This discontinuous nature of the aquifer system is also the reason why drilled depths of boreholes vary significantly across the region (Figure 3). Aquifers at the northern border of the Niger Delta are more continental in character, being composed of thicker and coarser river sand coming from the hinter land and characterized by much fewer clay intercalations as evidenced in a lithologic map of the Benin Formation drawn from borehole lithologs in the different zones (Figure 3). They are also encountered at shallower depths, so that in most cases, an average depth of $60 \mathrm{~m}$ was considered adequate to obtain very potable freshwater and in reasonable quality and quantity. The sand is generally coarse to very coarse and laterally extensive, with highly pervious gravelly layers commonly encountered. 


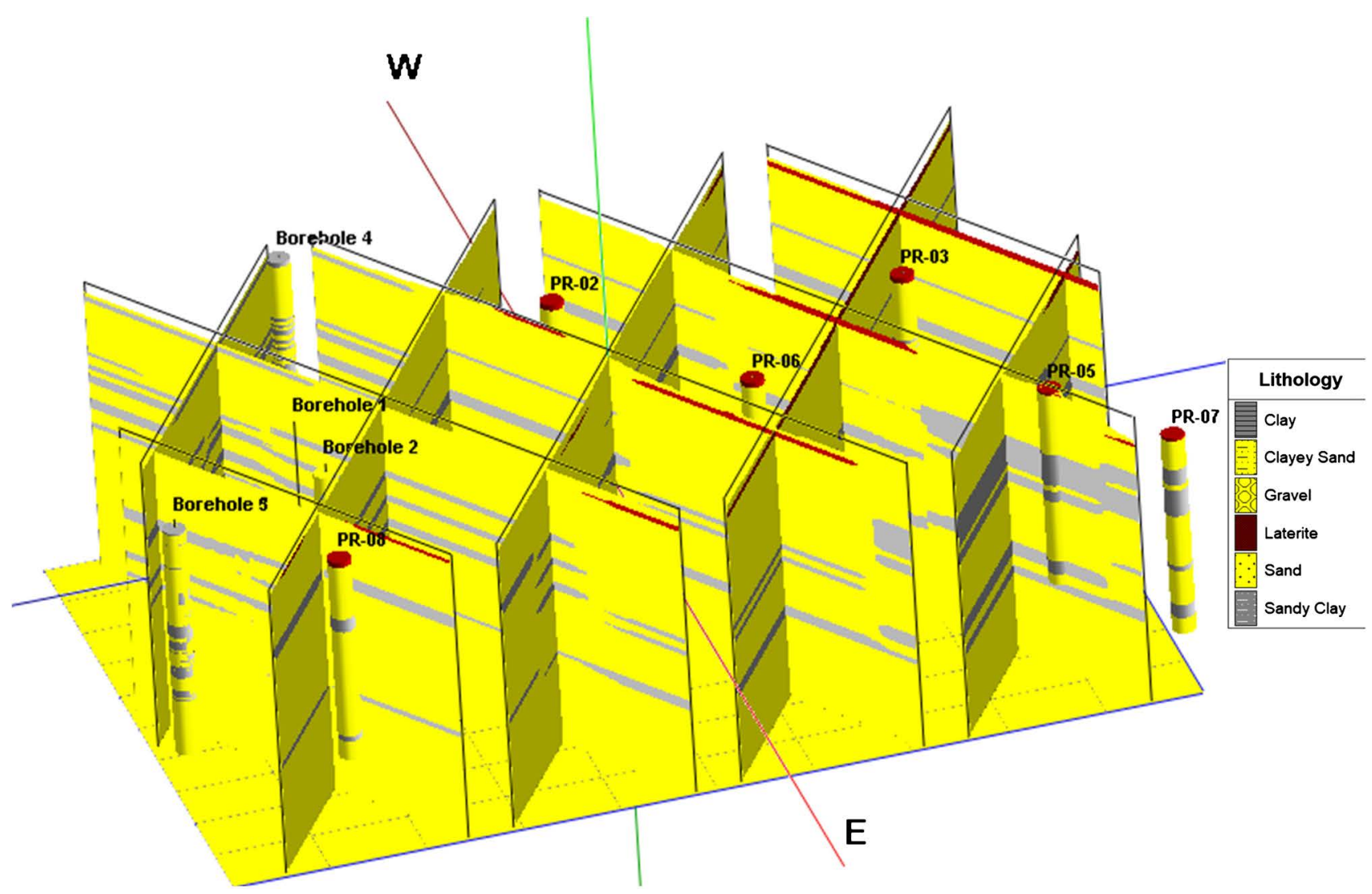

Figure 2. A fence diagram prepared with Rock Works showing an N-W view across Akpajo, Port Harcourt (the dark bands represent clay layers within the Benin Formation).

Ngah and Nwankwoala reported that borehole performances in terms of yield in this section have generally been impressive with excellent water quality [25]. This explains why majority of groundwater supply wells within the coastal plain sands, particularly domestic supply wells abstract water from these aquifers. Examples abound of such locations as Port Harcourt, Ogoni and Elele areas in the eastern Niger Delta and Aboh in the western Niger delta. Akpoborie presented typical lithologs of boreholes in western section of this zone predominated by coarse and gravelly sand over extended to $70 \mathrm{~m}$ depths which corroborates the lithologic map shown in Figure 3 [26].

A transitional zone lies within the lower section of the Meander belt and consists of freshwater swamps. This transitional zone is characterized by intricate and extensive meandering of rivers and the presence of lowland freshwater swamps. Surface runoff in this zone is subjected to some degree of tidal influence due to their proximity to the tidal estuary. The estuaries which embrace the western and eastern zones flanking the pro delta also have significant mangrove swamps that are associated with tidal inlets where saline water penetrates farther inland causing variable surface water quality arising from the mixture of fresh and saline waters.

A common feature of the transition zone is the comparatively more frequent presence of clay intercalations and embodiments within the aquifers. According 


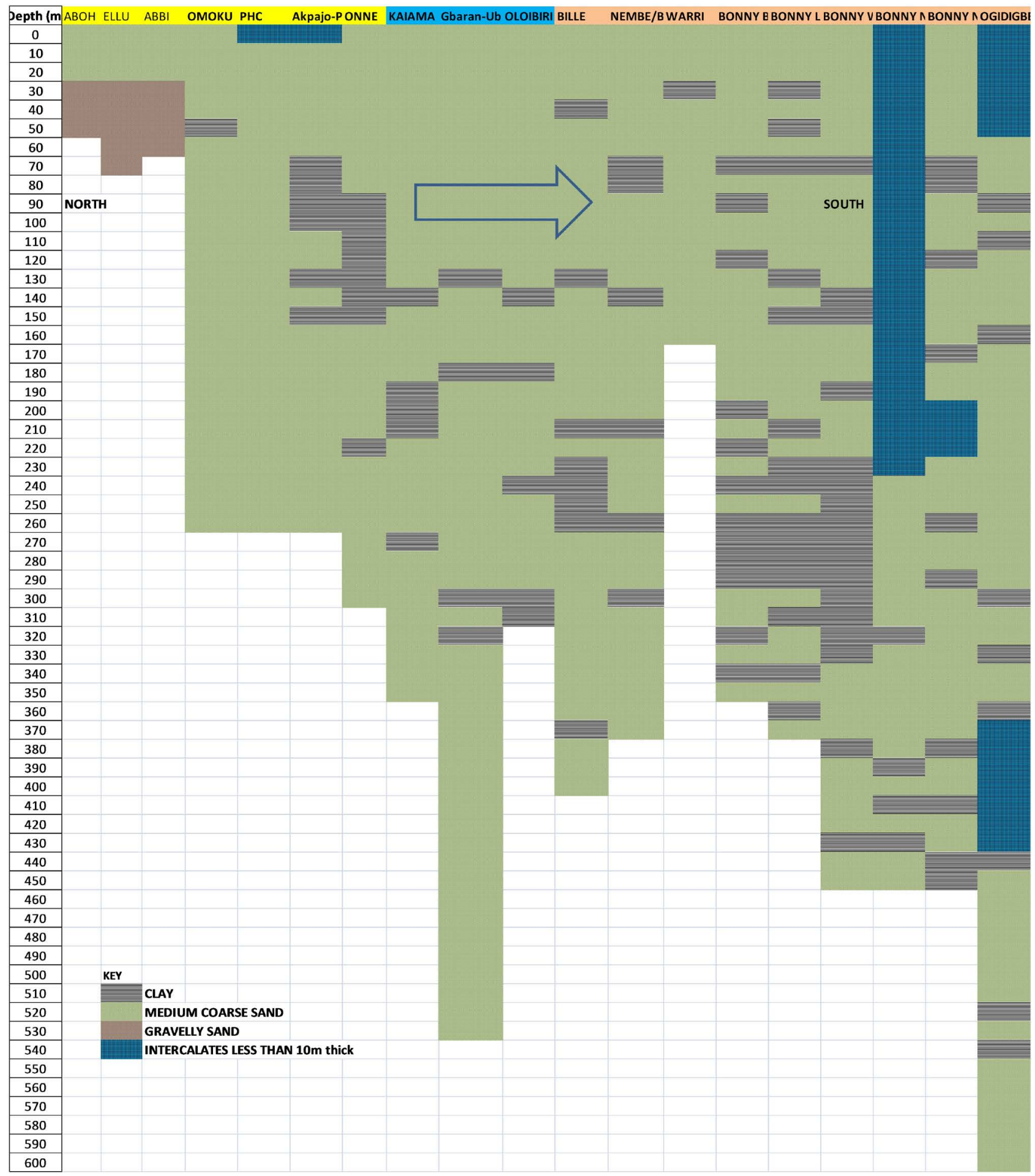

Figure 3. Lithologic Map of Benin Formation prepared from lithologs of deep wells in the Niger delta from Upstream (Left) to the Coastline (Right), showing the multi-aquifer system of the Niger Delta.

to Nwankwoala and Ngah these clay lenses are randomly distributed laterally and vertically within the zone [21]. In several cases, strata logs of wells in close proximity drilled less than $200 \mathrm{~m}$ apart, have been known to vary, and under such prevailing circumstance, prediction of aquifer thickness and performance 
in terms of produceability in the region is difficult. However, the freshwater swamps which constitute the front of the delta continue to indicate many features of continental environments, until very close to the coast. The aquifers in this zone may still be shallow, consisting of predominantly sand and gravelly materials, but clay intercalations become more prominent compared to the northern zone. The occasional occurrences of lignitic materials and partially decomposed vegetal matter reported by [27] [28] and [29] are indications of sedimentation under shallow water condition.

The coastal zone on the other hand borders the Atlantic Ocean and includes the mangrove swamp zone and beach ridges. Comparison of the occurrences and thicknesses of sand and clay in boreholes in the region (Table 2) show that stratification in this zone is characterized by far more frequent occurrences and thicker lenses of marine clay (Figure 3 and Table 2) with observable saline conditions in place as evidence of marine conditions of sedimentation. Clay occurrences account for at least $20 \%$ in total depth of drilled boreholes within this zone. The occurrence of thicker clay layers and higher frequency of clayey intercalations makes the prediction of productive horizons difficult, often requiring careful and detailed Gamma Ray logging. This is because, the clay horizon frequently escape detection in the traditional rotary/wash boring drilling technique used for deep wells.

Due to the proximity of the coastal zone to the ocean and the persistence of sand layer across the region, there is the possibility for marine conditions to penetrate further inland, resulting in a more complex zone with compromised

Table 2. Distribution of lithologies in Boreholes across the Niger Delta region.

\begin{tabular}{cccccc}
\hline Location & $\begin{array}{c}\text { Depth of BH } \\
(\mathrm{m})\end{array}$ & $\begin{array}{c}\text { No. of clay } \\
\text { layers }\end{array}$ & $\begin{array}{c}\text { Thickness of } \\
\text { clay }(\mathrm{m})\end{array}$ & $\begin{array}{c}\text { Thickness of } \\
\text { sand }(\mathrm{m})\end{array}$ & $\begin{array}{c}\text { Clay } \\
\text { thickness/Total } \\
\text { Depth of BH }\end{array}$ \\
\hline Onne & 300 & 2 & 85 & 215 & 0.283 \\
Omoku & 260 & 1 & 4 & 256 & 0.015 \\
Warri & 160 & 1 & 6 & 154 & 0.038 \\
Oloibiri/Otakeme & 277 & 4 & 26 & 277 & 0.094 \\
Kaiama & 348 & 3 & 34 & 270 & 0.098 \\
Gbaran-Ubie & 530 & 4 & 40 & 492 & 0.075 \\
Bille & 400 & 5 & 61 & 339 & 0.153 \\
Nembe/Basambiri & 366 & 5 & 78 & 288 & 0.213 \\
Bonny BRT & 360 & 8 & 109 & 251 & 0.303 \\
Bonny Life Camp & 362 & 12 & 143 & 219 & 0.395 \\
Bonny Water Board & 450 & 7 & 171 & 279 & 0.380 \\
Bonny NLNG Oguede & 452 & 6 & 155 & 297 & 0.343 \\
Bonny NLNG Finima & 450 & 10 & 109 & 341 & 0.242 \\
Ogidigbein/Ugborodo & 600 & 11 & 132 & 468 & 0.220 \\
\hline
\end{tabular}


water quality. Nearly all the aquifers in the region are overlain by sandy/silty clay or clay at near the surface, except in the coastal Beach Ridges where a thin surficial sand layer, 0.5 - $3 \mathrm{~m}$ thick, directly overlies relatively thick clay which in turn overlies the regional aquifer resulting in perched aquifers.

The combination of more frequent stratification and comparatively less bulky aquiferous horizons coupled with more widely variable hydraulic properties make the determination drilled depth and the choice of screened zone a complex subject. As a result, there are wide variations in depths of boreholes drilled in the region as shown in Appendix 1.

\section{Groundwater Recharge}

With rainfall varying from $2000 \mathrm{~mm}$ in the northern most section to $3600 \mathrm{~m}$ in Bonny and Brass at the coastline, it is reasonable to attribute the source of recharge of the aquifers in the region to precipitation. Precipitation generates about $70 \times 10^{6} \mathrm{~m}^{3}$ of fresh water per annum, $75 \%$ of which occurs between April and October of every year. Analysis of Rainfall and concurrent evaporation (Figure 4) indicates that $80 \%$ of the precipitation is lost to evapo-transpiration, leaving $20 \%$ which contributes to surface runoff and infiltration into the sub-surface to eventually recharge the groundwater. Groundwater recharge in the region estimated using the methods of Krishna [30] and Chaturvedi [31] gave values of $405 \mathrm{~mm}$ and $304 \mathrm{~mm}$ respectively.

An estimated groundwater recharge of $31.9 \mathrm{BCM} /$ year was predicted by JICA [1], for the Niger delta region of Nigeria. This value is just below that of the South East region which is the highest in Nigeria. The high perennial aquifer recharge in the area is supported by the abundant rainfall averaging 2532 $\mathrm{mm}$ /year, favorable geology, vast catchment area, North Southwards groundwater flow and presence of a rich network of fresh water rivers and streams in the area.

This meteoric water infiltrates through exposed outcrops of the Benin Formation

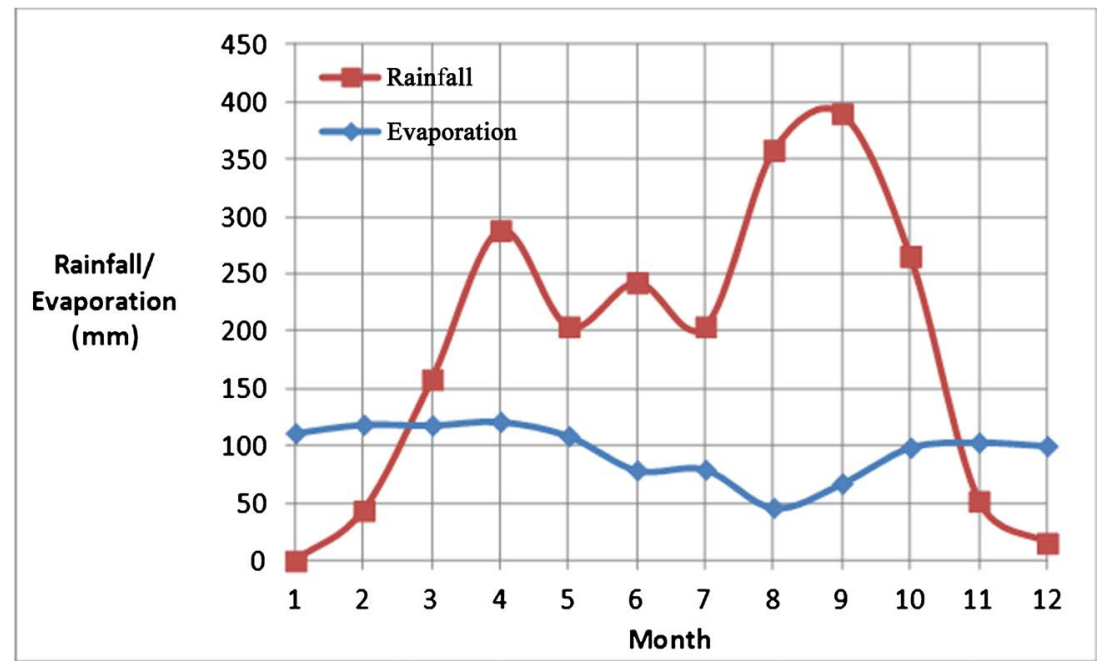

Figure 4. Rainfall and concurrent evaporation in the Niger Delta (Abam, 2016). 
mostly in the northern sections of the delta and through thin layers of overlying Quaternary sediments to recharge groundwater.

The thickness of the lateritic top and quaternary sediments over Benin Formation vary widely. Abam [32] reported values between $0-40 \mathrm{~m}$ as evident in Figure 5 where the ground surface elevation and depth to the top of Benin Formation between (a) Cawthorne Channel and Obrikom and (b) Omadino to Escravos for the southeastern and western sections, (c) Agbor to Sapele for the northwestern section is plotted.

According to Dickey et al., [33] and Amajor and Gbadebo [34], the extremely sandy and pervious nature of the upper Benin Formation permit meteoric water to penetrate deep into the subsurface. Areas where Benin Formation is exposed or close to the surface hardly experience flash floods, which is an indication that they are fairly pervious and well drained. The drainage qualities of these areas
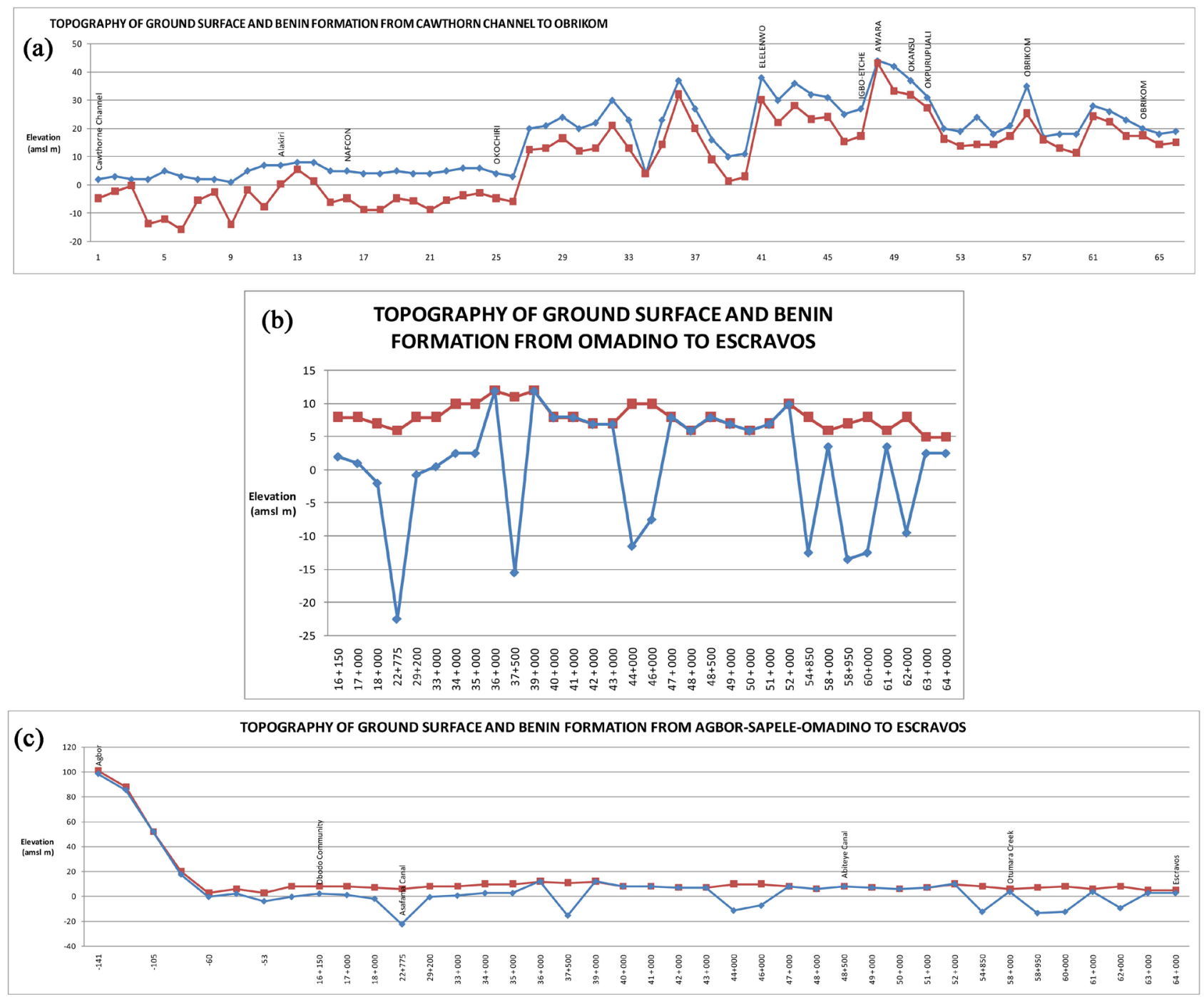

Figure 5. (a) Topography of Benin Formation in comparison to the ground surface in the Eastern Niger Delta; (b) Amplified section of Topography of Benin Formation within the Estuaries and Mangrove swamps Western Niger delta; (c) Topography of Benin Formation in comparison to the ground surface in the Western Niger delta. 
are confirmed by Particle size distribution analysis which shows that they comprise mostly of sandy clay and clayey sand, with effective particle size $D_{10}$ averaging $0.3 \mathrm{~mm}$ [32]. This is also an indication of the controlling effect of geology on groundwater occurrence in the Niger Delta.

Significant groundwater recharge also takes place through the Benin formation that is exposed beneath several river beds in the region. Sand search and ground investigation projects in river channels [35] reveal mostly monotonous sand formation on the Niger River at Okpai and Onitsha, extending from 0 to 40 $m$ depth. With ready supply of water in these rivers, the aquifer is constantly recharged through downward influent flow from the river channels. Such influent flow is also evident in hydrographs for Odofi River in Odokwa, Delta State, Nigeria reported by Akpoborie [26] which shows a significant contribution of upto $80 \%$ from base flow (Table 3 ) to gaining rivers. The groundwater level usually drops below the river water level, creating a hydraulic head differential which induces flow of river waters into the aquifers. The rivers, therefore, partly recharge the upper aquifers and could also pollute them with dissolved toxic or hazardous materials.

\section{Groundwater Level and Seasonal Variation}

Depth to static water level varies across the region (Table 4). The maximum static water level in the study area occurs around Ulakwo, at 18.2 meters below ground surface and Erema, 15.24 meters below ground surface in the northern parts of the study area. This is followed by the floodplain areas which recorded 0 - $5 \mathrm{~m}$, the Beach ridges $0-1.5 \mathrm{~m}$ and the mangrove swamp areas with depth to groundwater between $0-0.5 \mathrm{~m}$. The value approaches near surface in the southernmost parts and near the coast, $0.34 \mathrm{~m}$ at Abissa, $0.69 \mathrm{~m}$ at Brass and zero at Akassa.

Values of static water level are influenced by proximity to either the coastline or drainage rivers. This is why a decrease in static water level is observed in the central parts to $3.7 \mathrm{~m}, 3.23 \mathrm{~m}$ and $2.3 \mathrm{~m}$ for Omoku, Bodo and Abonema respectively where dense network of river systems interact with groundwater.

Artesian conditions prevail in places where a thick persistent clay sequence completely seals the underlying sandy aquifer over a long lateral distance with sufficient confining pressure as in the very deep wells at Bonny or in the perched aquifers in the clayey southern parts of the study area such as Okujagu Ama, Old

Table 3. Summary of flow statistics, Adofi River at Ossissa (Adapted from Akpoborie [26]).

\begin{tabular}{ccccccc}
\hline Statistic & 1989 & 1990 & 1991 & 1992 & 1993 & 1994 \\
\hline Minimum $\left(\mathrm{m}^{3} / \mathrm{s}\right)$ & 14 & 16 & 18 & 15.9 & 24.6 & 25.5 \\
Maximum $\left(\mathrm{m}^{3} / \mathrm{s}\right)$ & 41 & 47.5 & 49 & 46.2 & 53 & 54 \\
Mean $\left(\mathrm{m}^{3} / \mathrm{s}\right)$ & 21.321 & 23.591 & 25.618 & 22.355 & 31.87 & 36.668 \\
BFI & 0.855 & 0.845 & 0.832 & 0.844 & 0.872 & 0.868 \\
\hline
\end{tabular}


Table 4. Static water levels/piezometric levels and borehole locations in the study area (after Ngah \& Nwankwoala, [25]).

\begin{tabular}{|c|c|c|c|c|c|c|c|c|c|c|c|}
\hline S/NO & LOCATION & S.W.L (m) & S/NO & LOCATION & S.W.L (m) & S/NO & LOCATION & S.W.L (m) & S/NO & LOCATION & S.W.L (m) \\
\hline 1 & Ahoada & 7.2 & 30 & Baa Lenku & 10 & 59 & Alesa Eleme & 7.57 & 90 & Obite & 17.68 \\
\hline 2 & Ogbo & 7 & 31 & Bien Gwara & 9.14 & 60 & Ebubu & 6.1 & 91 & $\begin{array}{c}\text { Egbeke } \\
\text { Nanwuba }\end{array}$ & 9.14 \\
\hline 3 & Edocha & 4.26 & 32 & Baan & 6.1 & 61 & Bane & 15.24 & 92 & Umuechem & 10.26 \\
\hline 4 & Abua & 3.3 & 33 & Sii Babble & 9.45 & 62 & Bori & 14.02 & 93 & Rumuewhor & 5.5 \\
\hline 5 & Ndoni & 7.55 & 34 & Uegwere & 5.4 & 63 & Kpor & 9.14 & 94 & Okrika & 11.14 \\
\hline 6 & Idu & 6.2 & 35 & Tombia & 4.52 & 64 & Beeri & 10.41 & 95 & Ibuluya-Dikibo & 8.2 \\
\hline 7 & Ebubu & & 36 & Abonnema & 2.3 & 65 & & & 96 & & \\
\hline 8 & Omoku & 3.7 & 37 & Bakana & 1.25 & 66 & Bolo 1 & 5.49 & 97 & Amarata & 6.55 \\
\hline 9 & Obie & 7.6 & 38 & $\mathrm{Ke}$ & 2.16 & 67 & Kalio-Ama & 6.5 & 98 & Ukubie & 1.01 \\
\hline 10 & Erema & 15.24 & 39 & Abissa & 0.34 & 68 & Abam Ama & Artesian & 99 & Tebidaba & 2.04 \\
\hline 11 & Ubeta & 5.79 & 40 & Bille & 0.61 & 69 & Okujagu & 5.48 & 100 & Aguobiri & 3.6 \\
\hline 12 & Obagi & 5.49 & 41 & Buguma & 3.6 & 70 & George Ama & 0.61 & 101 & Koluama & 0.91 \\
\hline 13 & Bassambiri & 0.8 & 42 & Krakrama & 7.1 & 71 & Ogoloma & 0.9 & 102 & Olegbobiri & 6.7 \\
\hline 14 & Atubo & 1.37 & 43 & Abalama & & 72 & Ogu & 5 & 103 & Gbaran & 4.37 \\
\hline 15 & Nembe & & 44 & Isiokpo & 15.24 & 73 & Daka-ama & 3.05 & 104 & Igbogene & 5.64 \\
\hline 16 & Ogbia & 2.5 & 45 & Ogbakiri & 11.9 & 74 & Kalaibiama & 1.2 & 105 & Okolobiri & 7.62 \\
\hline 17 & Brass & 0.69 & 46 & Omarelu & 15.24 & 75 & Bonny & 2.44 & 106 & Isampou & 4.57 \\
\hline 18 & Otegila & 4 & 47 & Egbede & & 76 & Iloma Opobo & 3 & 107 & Odi & 1.91 \\
\hline 19 & Okoroba & 0 & 48 & Elele & & 77 & Gborokiro & 1.6 & 108 & Kaiama & 3 \\
\hline 20 & Amakalakala & 9.14 & 49 & Igbodo & 25 & 78 & Ikuru & 2.5 & 109 & Agudama-Epie & 5.79 \\
\hline 21 & Otugidi & 0.91 & 50 & Ulakwo & 18.2 & 79 & Nkoro & 2.5 & 110 & Oporoma & 4.6 \\
\hline 22 & Otuesaga & 12.19 & 51 & Opiro & 13 & 80 & Abalamabie & 1.5 & 111 & Korokorosei & 3.7 \\
\hline 23 & Akassa & 0 & 52 & Rumuonye & 22 & 81 & Queens Town & 1 & 112 & Yenagoa & 5.5 \\
\hline 24 & Kolo & NA & 53 & Chokocho & 10.3 & 82 & $\begin{array}{c}\text { Minima } \\
\text { Opobo }\end{array}$ & 3 & 113 & Forupa & 1 \\
\hline 25 & $\begin{array}{c}\text { Onne } \\
\text { (NAFCON) }\end{array}$ & 7.49 & 54 & Egwi & 8.25 & 83 & Oloma II & 5.49 & 114 & Agbere Odoni & 5.6 \\
\hline 26 & Bodo & 3.23 & 55 & Odagwa & 4.57 & 84 & Oloma I & 2.7 & 115 & Ekeremor & 1.2 \\
\hline 27 & Buan & 6.1 & 56 & Okehi & 24.23 & 85 & NDBDA & 9 & 116 & Toru Ndoro & 1 \\
\hline 28 & Govt. House & & 57 & Ofoni & 4 & 86 & Borokiri & 4 & 117 & Torofani & 5.5 \\
\hline 29 & Forupa & 1 & 58 & Amabulou & 2.1 & 87 & Letugbene & 1.5 & & & \\
\hline
\end{tabular}

GRA and Iva Valley, Port Harcourt. The water levels measured in these boreholes seem to fluctuate with season across the delta between $3 \mathrm{~m}$ and 8.3 meters above sea level [32]. Daily, 3-day and 5-day running averages and monthly variations of rainfall are explored to assess the influence of rainfall on the groundwater fluctuation (Figure 6). Historical data on the response of groundwater 

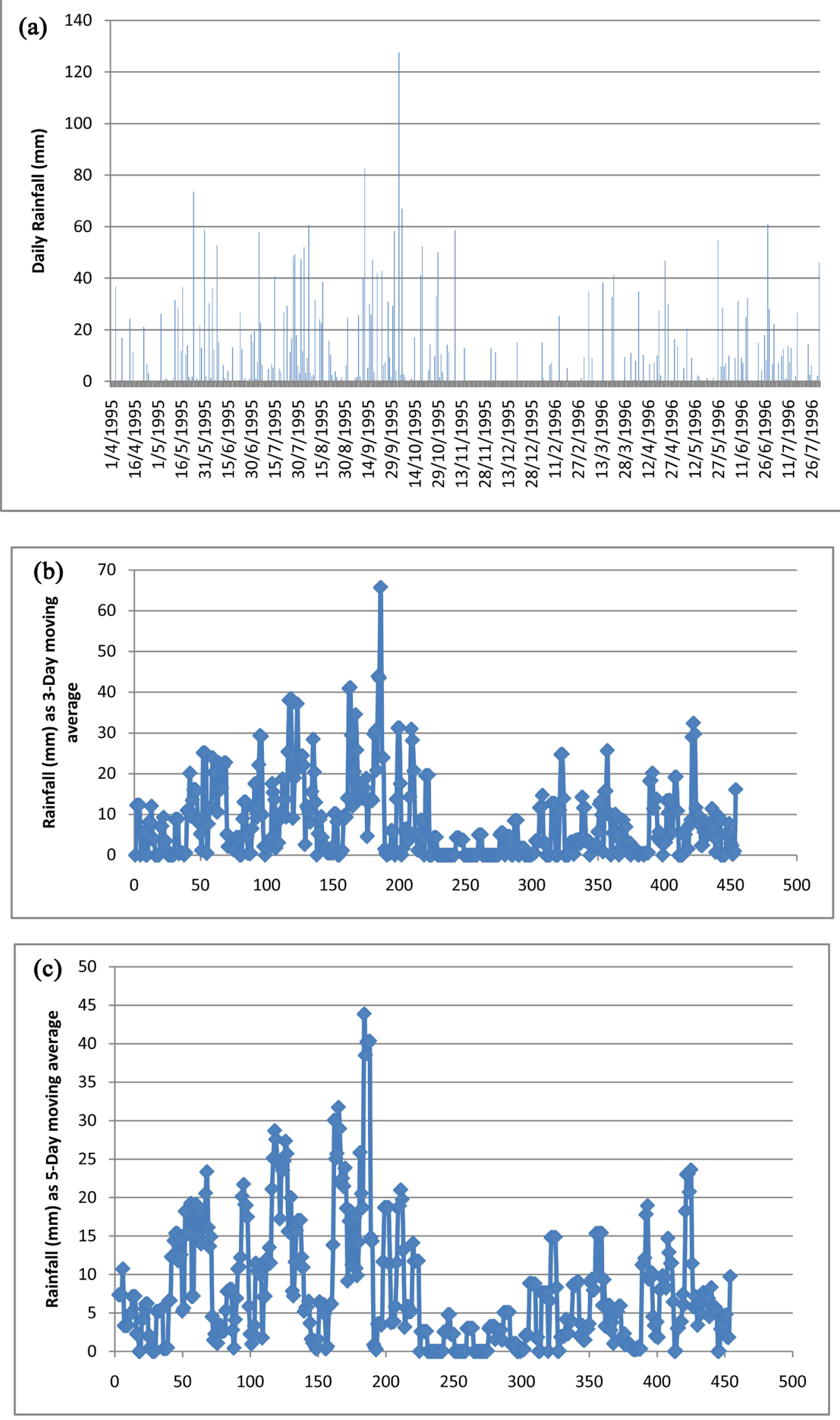


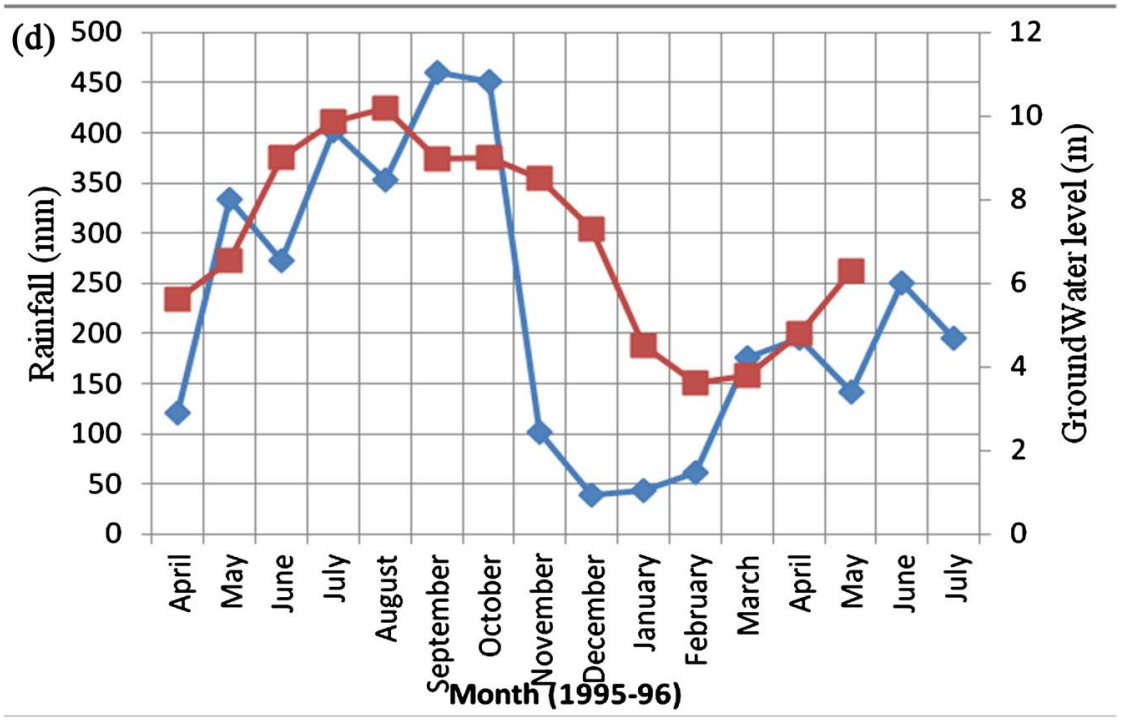

Figure 6. Rainfall distribution and groundwater level response in the Niger delta. (a) Daily Rainfall distribution; (b) 3-Daily running average of Rainfall distribution; (c) 3-Daily running average of Rainfall distribution; (d) Monthly Rainfall distribution and groundwater level response.

level to monthly rainfall distribution for the Eleme-Okochiri area behind the Port Harcourt Refinery Company show their seasonal variation (Figure 6) [32]. In general the higher values are obtained from the north and the lower values in the southern part.

After the cessation of rainfall in October, the groundwater level experiences a gradual recession, reflecting the absence of groundwater recharge and dominant effect of evapo-transpiration. The groundwater level, although season dependent, also vary across the Niger Delta region. Groundwater levels fluctuate in response to rainfall distribution in all but the mangrove swamp sub-environment.

Ngah and Nwankwoala [25] also observed variation in static water level between deeper and shallower aquifers. In deeper aquifers, water levels vary from 6.0 meters to 1.4 meters below ground level possibly due to exposure to variable artesian conditions. When compared with the water level data from the shallower aquifers which is much less variable. This could indicate a separation between the aquifers with the highest level in the deeper aquifers.

\section{Aquifer Hydraulic Properties}

Due to the persistence of the Benin Formation, the hydrogeological data in the up land areas of the Niger Delta have very broad similarities not only on the sub surface lithology but also in the overall aquifer hydraulic properties of permeability, storativity and specific capacity. This agrees with the observation of Ngah [36] that the producing aquifers in Bodo $(80 \mathrm{~m})$ Kono $(55 \mathrm{~m})$ also have permeability and specific capacity as well as storativity of same orders of magnitudes as the boreholes drilled in Trans Amadi in Port Harcourt and Umuayagu in Etche Local Government Area, even though they are more than $70 \mathrm{~km}$ apart. Similarly 
the producing boreholes in Sakpenwa are quite similar in hydraulic properties to the boreholes in Ahoada and Ikwerre Local government areas separated by 80 $\mathrm{km}$.

According to Offodile, the hydraulic conductivities of the sand units in Benin Formation vary from $3.82 \times 10^{-3}$ to $9.0 \times 10^{-2} \mathrm{~cm} / \mathrm{sec}$ indicating a potentially productive aquifer [37]. The transmissivity values for the aquifers across the Niger delta region range from $1.05 \times 10^{-3}$ to $11.3 \times 10^{-2} \mathrm{~m}^{2} / \mathrm{sec}$, while the coefficient of storage varies between $1.07 \times 10^{-4}$ and $3.53 \times 10^{-4}$ and specific capacity values lie between 19.01 and $139.8 \mathrm{~m}^{3} / \mathrm{h} / \mathrm{m}$ drawdown.

These values suggest that the aquifers have very good capacity to transmit groundwater. The specific capacity of a well is its yield per unit drawdown, usually expressed in $\mathrm{m}^{3} / \mathrm{hr} / \mathrm{m}$ of drawdown. It decreases in direct proportion with drawdown. Its maximum corresponds to zero drawdown while the minimum occurs when the drawdown and yield are at the maximum [38] and [39].

Summary aquifer hydraulic parameters for selected boreholes in the region are shown in Table 5. This shows that average specific capacity from boreholes (the yield per unit drawdown) for the upper and lower aquifers vary significantly. The average specific capacity for the upper aquifer is

$Q / S_{w}=19.4 \mathrm{~m}^{3} / \mathrm{h} / \mathrm{m}$, with a maximum value for the upper aquifer of 75.1 $\mathrm{m}^{3} / \mathrm{h} / \mathrm{m}$.

The Maximum noted value of specific capacity for deeper aquifer for which relatively fewer boreholes were investigated was $139.7 \mathrm{~m} / \mathrm{h} / \mathrm{m}$, and was recorded in Eleme, Akpajo and Onne areas of Ogoni land.

The hydraulic properties for the aquifers underlying the major urban area of PortHarcourt are summarized in Table 6.

This shows that as expected the values obtained from pumping test are significantly higher compared to those obtained using specific capacity data, and also that the deeper aquifer is exhibited comparatively higher transmissivity. Both the upper and lower aquifers are considered to be of the leaky artesian type. This is understandable, judging from the variable thickness and non-persistent nature of the clay intercalations within the body of the aquifer.

\section{Regional Flow}

The regional groundwater flow direction is North-south Figure 7. A predominant north-to-south regional groundwater flow pattern was also confirmed by Akpoborie, [26] in the western Niger Delta as shown in (Figure 8(a)) except in the northeast (Imo River catchment area) where the flow is northeast to southwest. Similarly, a groundwater map produced for the Akpajo area of Rivers State (Figure $8(\mathrm{~b})$ ) for an area covering $25 \mathrm{~km}^{2}$, reveals a predominantly Northeast-Southwest direction.

Changes in groundwater flow directions which occur at some places in the southeast, northwest and northeast generally serve localized discharge areas. The resultant flow path eventually joins and feeds the major regional north-south 
Table 5. Estimated values of hydraulic parameters compiled from published data for aquifers in the study area.

\begin{tabular}{|c|c|c|c|c|c|c|c|}
\hline S/No & Location & BH\#/Aquifer* & Depth (m) & Transmissivity $\left(\mathrm{m}^{2} / \mathrm{sec}\right)$ & $\mathrm{K}$ (m/day) & Storativity (s) & $\begin{array}{l}\text { Specific Capacity } \\
\qquad\left(\mathrm{m}^{3} / \mathrm{hr} / \mathrm{m}\right)\end{array}$ \\
\hline 1 & Moscow Road & 1 & & $5.52 \times 10^{-3}$ & 20 & $7.2 \times 10^{-5}$ & 69.44 \\
\hline 2 & Moscow Road & 2 & & $20.6 \times 10^{-3}$ & 148.4 & $3.6 \times 10^{-5}$ & 98.82 \\
\hline 3 & Moscow Road & 3 & & $56.1 \times 10^{-3}$ & 110.2 & $13.2 \times 10^{-5}$ & 26.39 \\
\hline 4 & Moscow Road & 4 & & $30.72 \times 10^{-3}$ & 66.36 & $12 \times 10^{-5}$ & 28 \\
\hline 5 & Borokiri & 1 & & $1.70 \times 10^{-3}$ & 4.474 & $9.9 \times 10^{-5}$ & 27.81 \\
\hline 6 & Borokiri & 2 & & $4.54 \times 10^{-3}$ & 18.7 & $6.3 \times 10^{-5}$ & 65.86 \\
\hline 7 & P/H Int'l Airport & 4 & & $4.97 \times 10^{-3}$ & 14.32 & $9.0 \times 10^{-5}$ & 5.13 \\
\hline 8 & Eleme Petrochemical & 2 & 230 & $43.6 \times 10^{-3}$ & 38.9 & $29.1 \times 10^{-5}$ & 48.73 \\
\hline 9 & Eleme Petrochemical & 3 & 222 & $52 \times 10^{-3}$ & 46.4 & $29.1 \times 10^{-5}$ & 78.13 \\
\hline 10 & Eleme Petrochemical & 5 & 235 & $65.6 \times 10^{-3}$ & 60.38 & $28.2 \times 10^{-5}$ & 52.08 \\
\hline 11 & Eleme Petrochemical & 6 & & $73.5 \times 10^{-3}$ & 65.54 & $29.1 \times 10^{-5}$ & 69.25 \\
\hline 12 & Eleme Petrochemical & 7 & & $69 \times 10^{-3}$ & 63.42 & $28.2 \times 10^{-5}$ & 43.55 \\
\hline 13 & Eleme Petrochemical & 8 & & $35.8 \times 10^{-3}$ & 32.94 & $28.2 \times 10^{-5}$ & 48.92 \\
\hline 14 & Rumuola -I & 4 & & $5.05 \times 10^{-3}$ & 14.56 & $9.0 \times 10^{-5}$ & 20.07 \\
\hline 15 & Rumuola -II & 8 & & $5.02 \times 10^{-3}$ & 9.44 & $13.8 \times 10^{-5}$ & 59.52 \\
\hline 16 & Rumuola 40 & 40 & & $26.4 \times 10^{-3}$ & & & 59.6 \\
\hline 17 & Rumuola 41 & 41 & & $31.9 \times 10^{-3}$ & & & 71.3 \\
\hline 18 & Rumuola 42 & 42 & & $33.2 \times 10^{-3}$ & & & 74.2 \\
\hline 19 & Woji & 1 & & $12.01 \times 10^{-3}$ & 49.42 & $6.3 \times 10^{-5}$ & 78.16 \\
\hline 20 & Trans-Amadi & 1 & 240 & $25.09 \times 10^{-3}$ & 114.1 & $5.7 \times 10^{-5}$ & 13.62 \\
\hline 21 & Trans-Amadi & 30 & & $3.6 \times 10^{-3}$ & & & 9.1 \\
\hline 22 & Trans-Amadi & 31 & & $5.5 \times 10^{-3}$ & & & 13.6 \\
\hline 23 & Trans-Amadi & 32 & & $7.4 \times 10^{-3}$ & & & 17.8 \\
\hline 24 & Fire Service, PH & 1 & & $2.44 \times 10^{-3}$ & 10.56 & $6.0 \times 10^{-5}$ & 30.61 \\
\hline 25 & Obite Gas Plant & 1 & & $33.1 \times 10^{-3}$ & 22.052 & $39.0 \times 10^{-5}$ & 19.75 \\
\hline 26 & Brass NAOC & 1 & & $17.19 \times 10^{-3}$ & 40.146 & $11.1 \times 10^{-5}$ & 20.08 \\
\hline 27 & Bori & $1^{*}$ & 33 & $1.05 \times 10^{-2}$ & 27.73 & $3.21 \times 10^{-4}$ & 19.01 \\
\hline 28 & Yenegoa & $1^{*}$ & 40 & $8.58 \times 10^{-2}$ & 30.5 & $3.53 \times 10^{-4}$ & 55.2 \\
\hline 29 & Isiokpo & $1^{*}$ & 38 & $2.1 \times 10^{-2}$ & - & - & - \\
\hline 30 & Choba & $1^{*}$ & 40 & $1.06 \times 10^{-2}$ & - & - & - \\
\hline 31 & Omoku & $1^{*}$ & 37 & $1.12 \times 10^{-2}$ & - & - & - \\
\hline 32 & Nembe & $2^{*}$ & 65 & $3.82 \times 10^{-2}$ & 9.25 & $1.07 \times 10^{-4}$ & 75.1 \\
\hline 33 & PHC, Moscow RD & $2^{*}$ & 165 & $5.1 \times 10^{-2}$ & - & - & 130.1 \\
\hline 34 & PHC, Elelenwo & $2^{*}$ & 151 & $8.79 \times 10^{-2}$ & - & - & 128.7 \\
\hline 35 & Eleme & $4^{*}$ & 302 & $11.3 \times 10^{-2}$ & 23.76 & $2.75 \times 10^{-4}$ & 139.8 \\
\hline 36 & Akpajo & $4^{\star}$ & 300 & $7.18 \times 10^{-2}$ & - & - & 130 \\
\hline 37 & Onne & $5^{*}$ & 300 & $4.14 \times 10^{-2}$ & - & - & 130.1 \\
\hline
\end{tabular}


Table 6. Summary hydraulic parameters for upper and deeper aquifers in Portharcourt urban.

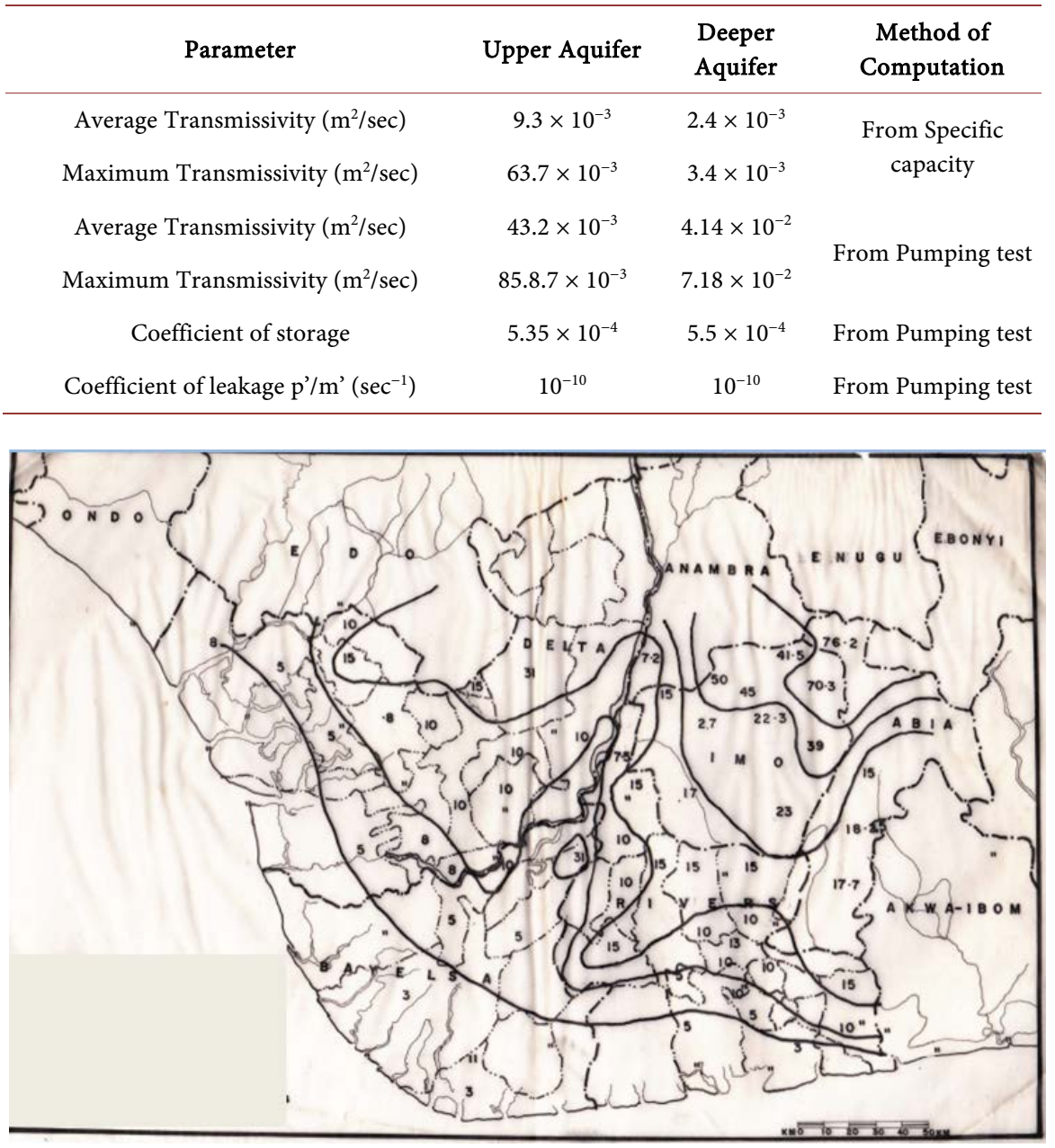

Figure 7. Regional Static Water Level Map of the Niger Delta.

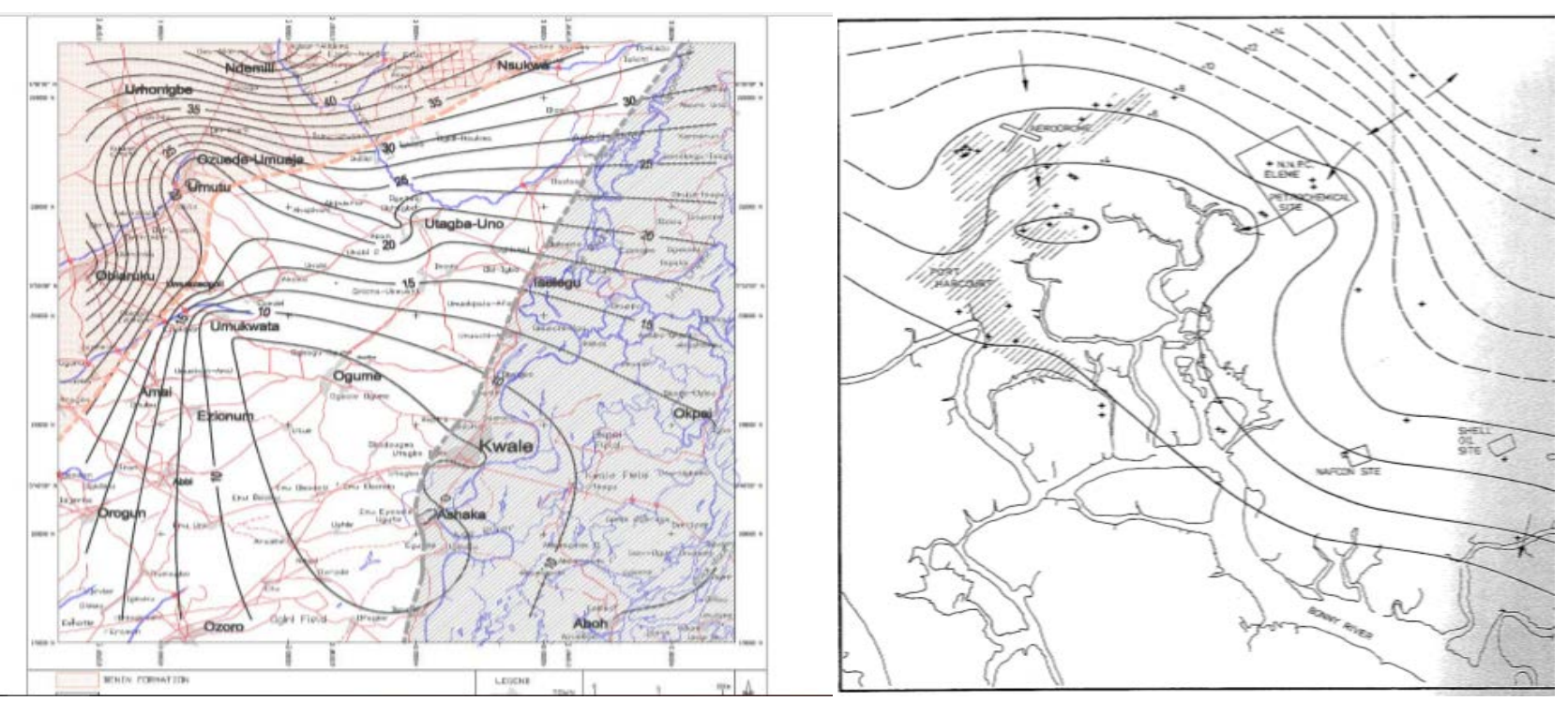

Figure 8. Equipotentials and Regional flow direction Western (Ndokwa) [26] and Eastern Niger Delta (Akpajo), PortHarcourt. 
flow direction. This flow pattern (local and regional) is generally consistent with the geology and stratigraphy of the area [25]. Groundwater flow in the region is gravity-induced and is responsible for recharging deep horizons of the subsurface.

The north-south regional groundwater flow direction is also supported by plotting a linear graph of direct static water level reduced to datum between Omoku and Cawthorne channel (Figure 9) across a distance of $187 \mathrm{~km}$, which reveal a hydraulic gradient of $3.8 \times 10^{-4}$.

It also shows localized flows that are not in the regional north-south direction, but towards flood plains areas with lower hydraulic heads. Furthermore, it reveals the potential occurrences of spring at interface of coastal plain sand with mangrove swamps.

\section{Groundwater Quality}

Freshwater quality and availability remain the most critical environmental and sustainability issues of the twenty-first century [40]. For a geographical area still populated by relatively low-income residents dependent on shallow unlined wells that are vulnerable to pollution, it was considered significant to assess water quality in such shallow wells. Table 7 presents the summary of water quality indices of some wells around PortHarcourt. By comparing this with water quality in deeper aquifers, it could offer clues as to the role of groundwater travel history in the area and the possible renovation that has taken place. As can be observed some well became dry in the dry season due to reduced groundwater recharge from rainfall.

At deeper levels in general, the quality of groundwater in the Niger Delta closely follows the sedimentation pattern [25]. Consequently, understanding of the spatial and stratigraphic distribution of the quality of water throughout the Niger Delta is of paramount importance in the pursuit for the provision of potable water.

Results of groundwater quality measurement for selected communities within the Niger Delta are presented in Appendix 2, Based on water quality, three distinct

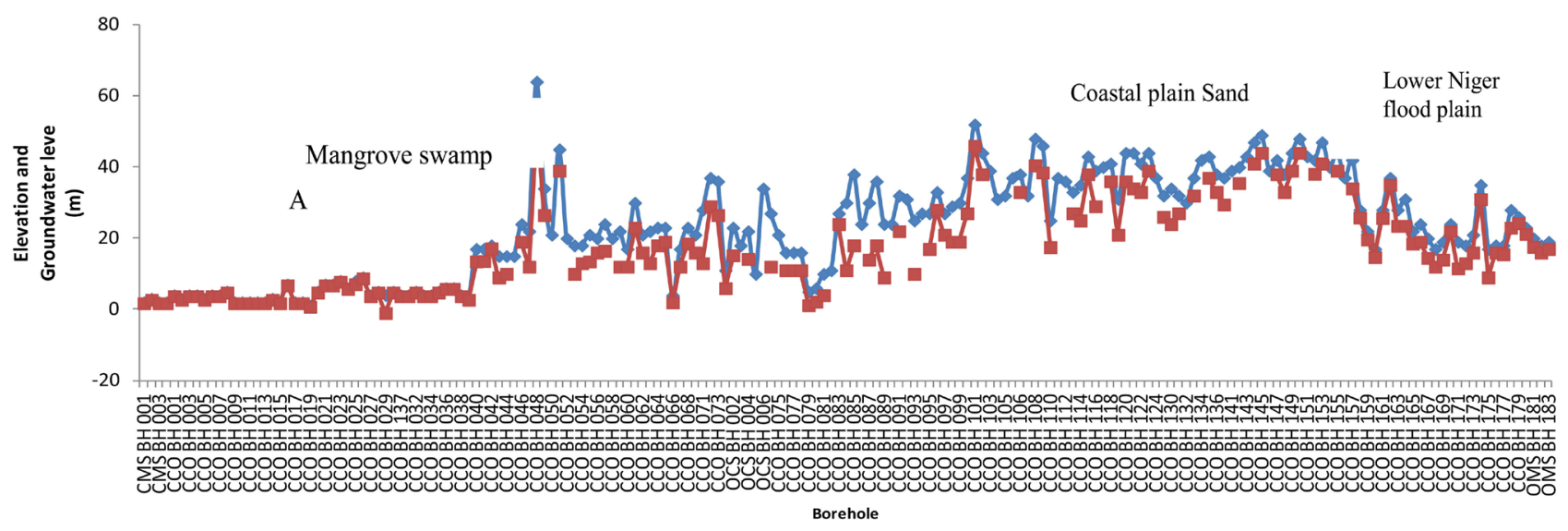

Figure 9. Groundwater surface elevation along the traverse in the Eastern Niger delta (Adopted from Abam, [32]). 
Table 7. Summary of Dry season well water quality around Port Harcourt.

\begin{tabular}{|c|c|c|c|c|c|c|c|c|c|c|c|c|c|c|c|c|}
\hline 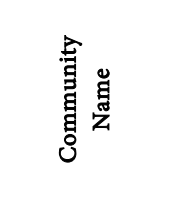 & $\begin{array}{l}\text { 营 } \\
\text { z }\end{array}$ & $\begin{array}{l}\text { 㺃 } \\
\text { 焉 }\end{array}$ & 窇 & 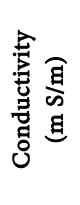 & 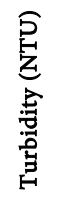 & 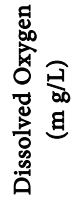 & 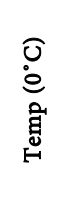 & 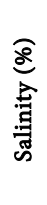 & 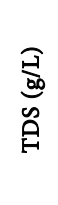 & 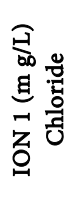 & 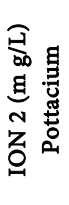 & 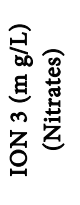 & 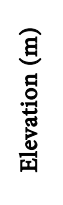 & 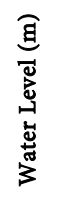 & 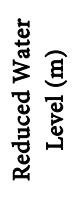 & 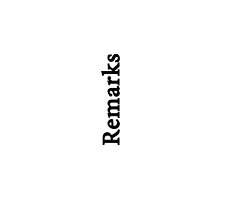 \\
\hline Omodu-Aluu I & $04^{\circ} 56^{\prime} 33.90^{\prime \prime}$ & $06^{\circ} 55^{\prime} 50.50^{\prime \prime}$ & & & & & & & & & & & 19.0 & 8.30 & - & Dry Well \\
\hline Omodu-Aluu II & $04^{\circ} 56^{\prime} 33.80^{\prime \prime}$ & $06^{\circ} 55^{\prime} 45.50^{\prime \prime}$ & 5.70 & 41 & 44 & 5.0 & 30.5 & 0 & 0.27 & 5.91 & 0.10 & 91 & 17.0 & 7.50 & 9.50 & Milky water color \\
\hline Mbodo-Gbalam & $04^{\circ} 62^{\prime} 5.90^{\prime \prime}$ & $06^{\circ} 57^{\prime} 45.10^{\prime \prime}$ & 6.06 & 24 & 300 & 3.6 & 29.8 & 0 & 0.18 & 1.50 & 0.10 & 3.2 & 33.0 & 4.10 & 28.90 & $\begin{array}{l}\text { Dirty Water Color } \\
\text { due to high Turbidity }\end{array}$ \\
\hline Igwuruta Ali & $05^{\circ} 58^{\prime} 18.0^{\prime \prime}$ & $06^{\circ} 59^{\prime} 19.12^{\prime \prime}$ & & & & & & & & & & & 28.0 & 8.30 & - & Dry Well \\
\hline Rukpokwu I & $05^{\circ} 54^{\prime} 0.38^{\prime \prime}$ & $06^{\circ} 59^{\prime} 21.30^{\prime \prime}$ & 5.68 & 7 & 120 & 3.5 & 28.56 & 0 & 0.04 & 0.49 & 0.10 & 1.1 & 18.0 & 2.60 & 15.40 & $\begin{array}{l}\text { Dirty Water Color } \\
\text { due to high Turbidity }\end{array}$ \\
\hline Omagwa III & $04^{\circ} 59^{\prime} 12.7^{\prime \prime}$ & $06^{\circ} 55^{\prime} 35.1^{\prime \prime}$ & 5.16 & 1.0 & 110 & 8.4 & 29.7 & 0 & 0.00 & 0.43 & 0.10 & 5.9 & 29.0 & 4.10 & 24.90 & $\begin{array}{l}\text { Milky Water color } \\
\text { due to turbidity }\end{array}$ \\
\hline Rumuosi I & $04^{\circ} 52^{\prime} 47.2^{\prime \prime}$ & $06^{\circ} 56^{\prime} 26.8^{\prime \prime}$ & 4.67 & 77 & 28 & 9.3 & 28.9 & 0 & 0.50 & 7.68 & 0.10 & 99 & 14.0 & 9.90 & 4.10 & Colorless Water \\
\hline Rumuosi II & $04^{\circ} 52^{\prime} 47.1^{\prime \prime}$ & $06^{\circ} 56^{\prime} 27.2^{\prime \prime}$ & 4.70 & 22 & 20 & 5.6 & 27.7 & 0 & 0.15 & 1.10 & 0.10 & 19 & 23.0 & 10.0 & 13.0 & Colorless Water \\
\hline Ozuoba I & $04^{\circ} 52^{\prime} 14.9^{\prime \prime}$ & $06^{\circ} 55^{\prime} 58.5^{\prime \prime}$ & 4.17 & 31 & 17 & 5.8 & 28.3 & 0 & 0.20 & 1.70 & 0.10 & 17 & 26.0 & 9.40 & 16.60 & Colorless Water \\
\hline Ozuoba II & $04^{\circ} 52^{\prime} 18.9^{\prime \prime}$ & $06^{\circ} 55^{\prime} 51.5^{\prime \prime}$ & 4.60 & 44 & 30 & 7.8 & 27.7 & 0 & 0.28 & 3.80 & 0.10 & 4.8 & 26.0 & 9.70 & 16.30 & Colorless Water \\
\hline $\begin{array}{l}\text { Rumuikwunga- } \\
\text { Rumukwachi I }\end{array}$ & $04^{\circ} 52^{\prime} 00.6^{\prime \prime}$ & $06^{\circ} 55^{\prime} 35.3^{\prime \prime}$ & 4.67 & 0 & 43 & 7.9 & 28.0 & 0 & 0.00 & 0.627 & 0.10 & 85 & 18.0 & 7.64 & 10.36 & Translucent Water \\
\hline $\begin{array}{l}\text { Rumuikwunga- } \\
\text { Rumukwachi II }\end{array}$ & $04^{\circ} 51^{\prime} 59.1^{\prime \prime}$ & $06^{\circ} 55^{\prime} 35.3^{\prime \prime}$ & 5.47 & 60 & 42 & 7.8 & 28.0 & 0 & 0.38 & 4.34 & 0.10 & 20 & 13.0 & 6.90 & 6.1 & Colorless Water \\
\hline Ogbogor I & $04^{\circ} 50^{\prime} 49.7^{\prime \prime}$ & $06^{\circ} 55^{\prime} 42.6^{\prime \prime}$ & 5.55 & 37 & 140 & 7.5 & 28.4 & 0 & 0.24 & 2.99 & 0.10 & 47 & 13.0 & 6.35 & 6.65 & Dirty Water \\
\hline Ogbogoro II & $04^{\circ} 50^{\prime} 53.4^{\prime \prime}$ & $06^{\circ} 55^{\prime} 42.5^{\prime \prime}$ & 4.22 & 33 & 25 & 7.9 & 28.9 & 0 & 0.21 & 3.52 & 0.10 & 1.3 & 10.0 & 7.21 & 2.79 & Colorless Water \\
\hline Oyigbo & $04^{\circ} 52^{\prime} 09.5^{\prime \prime}$ & $07^{\circ} 9^{\prime} 24.0^{\prime \prime}$ & 3.76 & 48 & 28 & 9.5 & 30.2 & 0 & 0.31 & 4.30 & 0.10 & 50 & 25.0 & 1.73 & 23.27 & Colorless Water \\
\hline
\end{tabular}

groundwater zones are recognized. The continental deposits of the Northern border produce water with the most desirable quality water in the region - fresh, pure and commonly uncontaminated groundwater. Within the transition zones, however, the complex sedimentary environment greatly influences the water quality. Most remarkable are the freshwater swamp lands where quality degradation associated with the breakdown of organic matter derived from vegetation buried in the sediments, are encountered. These generally take the form of high carbonate acidity and introduced hydrogen sulphide, commonly identified by the offensive smells of some water samples from the area.

The groundwater quality in these aquifers is considered very good and compares favorably with WHO as well as SON standards for drinking water. However, relatively high iron and chloride values are localized in time and space. Iron contamination in groundwater is widespread within the transition zones. The intensity of its occurrence has been observed to be higher within the Meander belt of the freshwater swamp zones $(4 ; 6,5)$. Also, significant iron contamination has been reported in the mangrove swamp land areas, notably $\mathrm{Bu}$ guma, Bonny and Abonnema in Rivers State [29]. They are commonly in the 
form of ferrous iron which generally remains in solution when water samples are freshly collected. However, upon exposure to the atmosphere, the ferrous iron comes in contact with oxygen in the air and is oxidized into its ferric equivalent which is generally brownish in colour. The acidic nature of groundwater, characterized by low $\mathrm{pH}$ ensures that iron and manganese remain in solution, both of which impart an unpleasant and unpalatable taste.

An important contribution to the quality of groundwater, especially in shallow aquifer is leachates from wastes dumps. The level of contamination from leachates emanating from dumpsites needs to be determined through a careful regional monitoring programme.

The source of the iron contamination has been a subject of debate but it is suggested to have been emplaced by iron fixing bacteria associated with sedimentary environments of decaying vegetative matter. The exposure of Quaternary sediments to glaciation was accompanied by eustatic lowering of the sea level such that could expose the sediments to the oxygen rich atmosphere and created paleo-soils rich in iron oxides [41] and [42]. The subsequent rise in sea level would have incorporated the paleo-soils into the geologic record.

Water quality is also greatly affected by dissolved solids which can be accumulated during the passage of water through the soil. These could form weak acids such as carbonic acid (formed by the dissolution of $\mathrm{CO}_{2}$ especially in the root zone) and humic acids (formed by the biological decomposition of organic matter). The salts and acids are added to the water as it infiltrates downward into the aquifer. However, due to evaporation which is very significant in the tropics, these salts tend to concentrate in shallower horizons and above the root zone.

The rate of movement and circulation of groundwater in deeper horizons greatly decreases due to significantly reduced hydraulic gradients. This in turn implies greater retention times which would allow more minerals to be dissolved so that concentration tends to increase with depth. This process can lead to a vertical stratification, with bicarbonates predominant in the upper zone and chlorides at depth [43].

Most managers of water resources treat surface water or groundwater as if they were separate entities in spite of their dynamic relationship which was described by Abam [44]. It is apparent that as demand for water resources increases, the development of either of these resources will inadvertently affect the quantity and quality of the other. Due to the geology of the Niger Delta, nearly all surface-water features (streams, lakes, reservoirs, wetlands, and estuaries) interact with groundwater. These interactions are most evident in the many coastal islands in the Niger Delta and take many forms. In some situations, surface-water bodies gain water from groundwater systems and in others the surface-water body is a source of groundwater recharge and causes changes in groundwater quality as well. As river water levels are lowered during annual flood recessions, groundwater seeps into the river channels. In the same manner, pumping in coastal aquifers causes saline seawater to migrate landwards to cause 
pollution. It follows therefore that pollution of surface water can cause degradation of groundwater quality and conversely pollution of groundwater can degrade surface water. Consequently an effective water resources management in the region requires a clear understanding of the linkages between ground water and surface water.

\section{Saline Intrusion and Salinity}

Saline water intrusion is a major source of pollution in the transition and coastal areas of the Niger Delta. As explained earlier, the persistence of sand layer cutting across zones and hydraulically bridging the transitional zones with saline water body thus creating the possibility for saline water to penetrate further inland, resulting in a more complex transition zone.

Deep sedimentary basins are often the source of connate water with little or no circulation and are usually of high salinity. Progradation over time could also result in the deep burial of pocket of saline water which reflects as low resistivity zone in well logs equated to saline intrusion.

In-hole resistivity logs run in the deep boreholes in parts of the study area captured the vertical distribution of saline water in the area. Salinity levels at depths in various locations within the region are shown in Appendix 3, while salinity trend (Figure 10) indicates a concentration of incidences of saline intrusion in the mangrove sub-environment and a possible spatial relationship between the points of concentration. Vertical distribution of salinity (Figure 11)

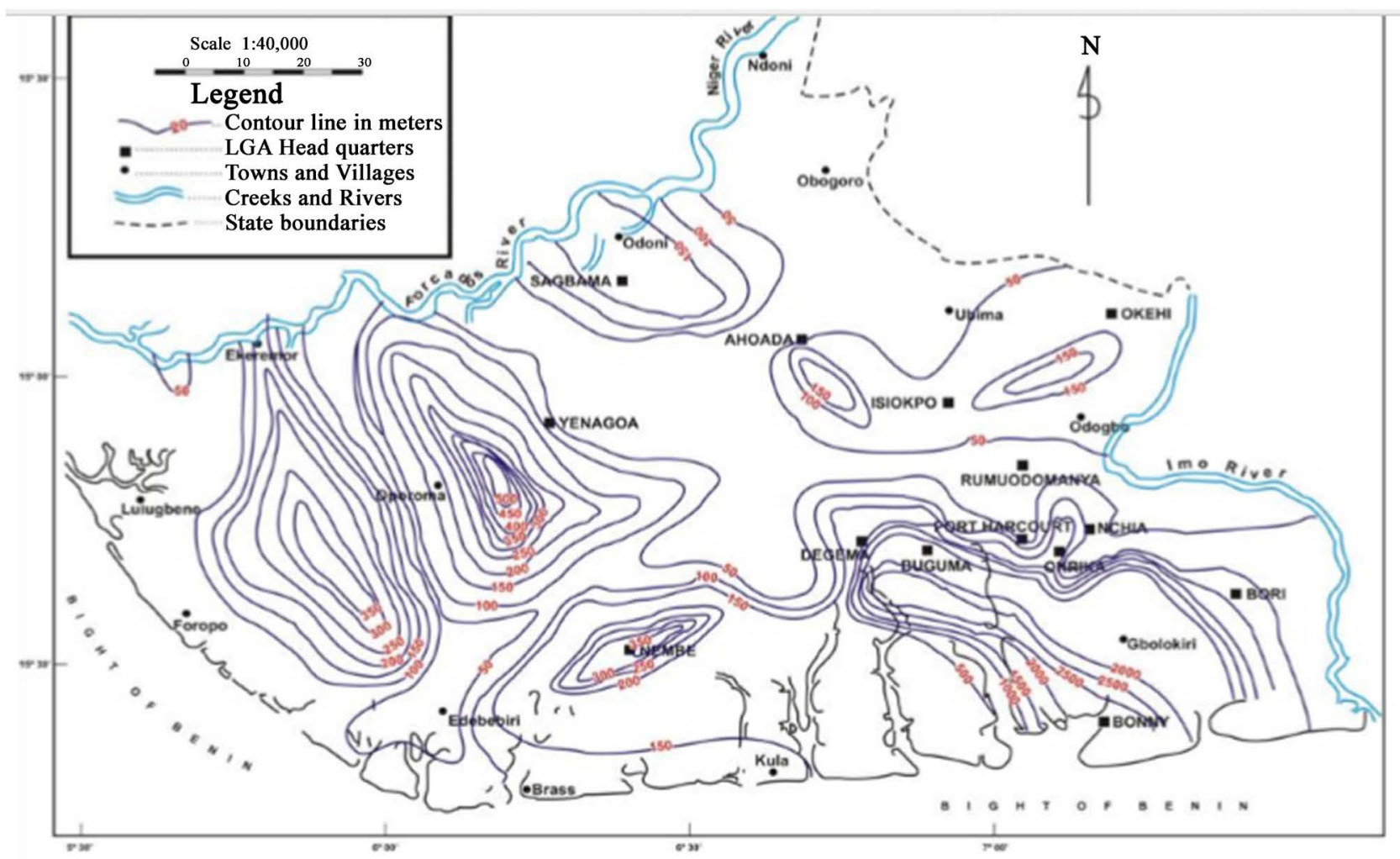

Figure 10. Salinity depths in the Niger Delta (after Ngah and Nwankwoala, [25]). 


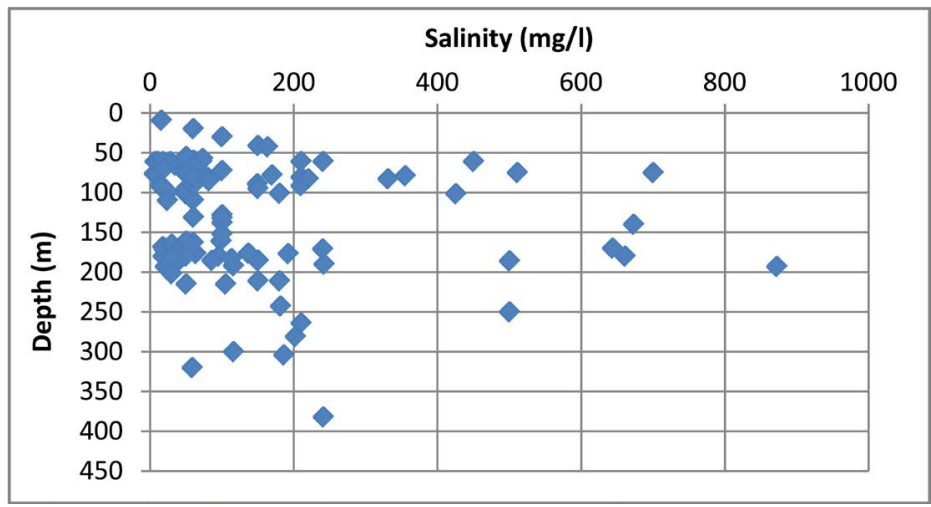

Figure 11. Salinity distribution with depth in the Niger Delta.

suggests that salinity tends to be higher with depth and with decreasing groundwater mobility, pointing to a possible connate origin of salinity in some cases.

Aquifer sections registering high salinity or affected by saline intrusion within the coastal areas can be extensive, for example Oguede, Bonny $(0-282 \mathrm{~m}), \mathrm{Fi}-$ nima (0 - $218 \mathrm{~m})$, BRT Bonny (0 - $215 \mathrm{~m}$ ), Mobile Life Camp Finima-1 \& 2 (0 $146 \mathrm{~m})$, Bille $(0-240 \mathrm{~m})$ and Ogidigbenu/Ugborodo $(0-418 \mathrm{~m})$. The high salinity at such depths in boreholes in coastal zone suggests saltwater intrusion from the submarine into freshwater aquifers. Naturally, the coastal aquifers drain into the ocean and are in contact with the ocean at the coastline where under natural conditions fresh water is discharged into the ocean. Excessive abstraction of groundwater will result in a decreased seaward flow of fresh groundwater causing saline water to enter and penetrate inland through submarine outcrops. According to Ngah, [29], this phenomenon will progressively displace the freshwater thereby increasing the salinity depth.

In the coastal islands, the shallow aquifer systems which occur as groundwater mounds are unprotected from the leacheates from wastes dumps and dynamic coastal activities. These aquifers are exposed to saline incursion during storm surges, rendering the groundwater unfit for human use. Exploitation of the shallow freshwater aquifers has also reduced the thickness and effective head of the freshwater mound, leading to saltwater intrusion into fresh water aquifers. Modeling studies of groundwater level response to industrial scale groundwater abstraction reveal that effects can be extended over $5 \mathrm{~km}$ radius and could as a consequence, lead rapidly to saline intrusion if such industrial infrastructure is within the coastline.

\section{Threats to Groundwater and Aquifer Vulnerability to Contamination}

This section highlights the activities and situations that could place the aquifers of the Niger Delta in danger of pollution. Aquifers can be polluted by a combination of factors: agricultural activities, petroleum leakage and spills, land disposal of solid wastes, sewage disposal on land, saltwater encroachment, deep well 
disposal of liquid wastes, mining activities, spread of urbanization to recharge areas, and seepage from industrial waste.

The first aquifer system is extremely vulnerable to pollution from surface sources because of its proximity to the ground surface. The cap to this aquifer consisting, mostly of laterized soil are not impermeable in many cases and therefore allow only some degree of infiltration/percolation from the surface into the aquifer. Several oedometer consolidation tests on these lateritic materials across the delta indicate average permeability of $1.6 \times 10^{-8} \mathrm{~m} / \mathrm{s}$ (Groundscan 2007). This translates to a travel distance of $0.5 \mathrm{~m} /$ year. In places where the lateritic cover is thin or nonexistent, undesirable pollutants from the various potential sources (including leaking hydrocarbon pipelines/storage tanks, farmlands, waste dump pits and soak-aways) can readily result in the contamination and seriously degrading groundwater quality. This scenario is already playing out several locations, for instance in Aba and Okrika mainland where leakages over extended periods in the NNPC (Nigeria National Petroleum Corporation) tank farm and depot and the network of hydrocarbon pipelines have grossly polluted the upper aquifer.

Deeper aquifer systems in the Niger delta are separated by fairly thick clay/shale layer which by their nature, are impermeable, serving as a barrier to vertical (down-ward) percolation of contaminants from the first aquifer. The attenuation properties of clay also lead to an overall reduction of potency of contaminants and possible elimination through cation exchange. For this reason, it can be assumed that the aquifer systems below the first are reasonably protected from pollution from surface sources. Pollution of second aquifer system from surface sources is therefore less likely, except through deep vertical leakage of the overlying aquitard and through poor borehole completion practices.

\section{Climate Change Impacts on Water Quality and its Implications}

The sustainability of water supplies under future climate scenarios depends on the quantity and quality of groundwater resources as well as the physical, chemical, biological and hydrogeological characteristics of the aquifers. Both thermal and chemical properties of groundwater may be affected by climate change. In shallow aquifers, groundwater temperatures may increase due to increasing air temperatures. Such a change in climate can cause a change in the rate of infiltration and leaching, or a change in the rate of evaporation. Additionally, even if climate change does not cause any significant changes in groundwater quality, changes in the amount of groundwater entering other water systems will change the quality of groundwater and those of other water systems [45].

The effects of climate change in the Niger Delta has not been studied in detail. However, Alley, Dragoni and Sukhija have projected that the variability in precipitation patterns will likely affect the quality of groundwater under future climate scenarios in many ways [46] [47]. Changes in recharge rates, mechanisms 
and locations will affect contaminant transport, and spatial and temporal variability in groundwater quality. Also, the spatiotemporal variability in precipitation patterns will result to substantial infiltration events. Reduced hydraulic gradients resulting from reductions in groundwater recharge could lead to longer residence times in aquifers; increased residence time allows greater water sediment interaction and typically leads to increased levels of salinity [48] and [49].

Globally, sea levels have risen by about $22 \mathrm{~cm}$ in the $20^{\text {th }}$ century. Sea levels are expected to continue to rise, probably increasingly rapidly, in response to global warming, as ocean waters warm and expand and major ice sheets melt into the seas [50]. In coastal areas, these higher sea levels are likely to increase the potential for intrusion of ocean water into shallow freshwater aquifers, thus threatening to increase groundwater salinity [51]. Sea-level rise, spatial and temporal variability in precipitation patterns and evapotranspiration, which affect recharge and increase groundwater abstraction, will result to increased saline-water intrusion into fresh groundwater [51] [52] [53] [54] and [55].

The increasing sea-level rise will lead to increased groundwater flow towards low-lying inlands areas and decrease groundwater flow towards the sea [55] and [56]. Thus, brackish and saline-water in the mangrove swamp areas will be pushed upstream, such that saline-water intrusion may increase in the low lying freshwater swamp areas; this will increase salinization and degrade groundwater quality in most low-lying areas and hence affect its ecology and drainage systems.

Due to subterranean freshwater seepages beneath the coastline, changes in groundwater quantity and quality may also influence ocean chemistry, especially near coasts. Decreased groundwater flow towards the sea could also potentially change the volume of groundwater discharging to the oceans by altering the magnitude and/or direction of the hydraulic gradient between aquifers and oceans.

If rainfall intensity increases, the current drive for intensification of agriculture could result in pollutants (pesticides, fertilizers, organic matter and heavy metals) being increasingly washed from soils to water bodies. Where recharge to aquifers occurs via these surface water bodies, groundwater quality is likely to decline. Consequently, potential effects that may result from changes in sea level and aquifer recharge could include the loss of potable water supplies from increased saltwater intrusion, as well as subsurface flooding of infrastructure from an increase in the height of the underlying water table. Besides, there could also be potential socioeconomic consequences of these effects, which could include the loss of developable property, including areas currently suitable for septic systems, as well as effects on the public-works infrastructure.

\section{The Way Forward}

Quite unfortunately, in spite of the fundamental role groundwater plays in human well being, as well as that of many ecosystems, groundwater basins are difficult to govern and manage, partly because of poor information, and also be- 
cause of poor visibility of the resource, the need for reliable data and information in support of water resource planning is central to any strategy. Technology, knowledge transfer and sound research cooperation should receive sufficient attention at the sub-national and national levels for any meaningful solution of regional groundwater problems.

More importantly, any sustainable suggestion towards the improvement of water resources management in the Niger Delta must include but not limited to the following:

1) Re-introduction of long-term hydrological observations and investigation of new data collection on water use, irrigation and agriculture lands, water sediment deposits, industrial demands, urban development, recharge, hydraulic properties as well as groundwater/surface water interaction;

2) Protection of groundwater resources to safeguard long-term use and balance the demands of economic development with ecosystem conservation;

3) Regional studies of hydrogeology, hydraulic properties, regional flow system and water quality that cross state boundaries;

4) Greater integration of the relevant information systems, e.g hydrology, hydrogeology, water quality, land use, sediment transport etc.;

5) The technical knowledge base on the impacts of climate change on water will have to be enhanced in order to be able to foresee and interpret more precisely the impacts of climate change on the components of the water cycle in the future, as well as outlining the actions to be carried out to cope with these changes.

6) Financial arrangements for state and urban water boards and basin authorities must be diversified (including using the public private partnership approach) in order to allow greater flexibility when facing the onset of unexpected occurrences, and so as to be able to relieve the current dependency on funds from the federal and state governments.

7) Better use must be made of existing science as well as investing in the research and development of new technologies to prepare a response that is more adapted to the challenge of climate change in the water sector.

8) Coordinated long-term national strategies for sustainably managing water in the face of climate change should be valued and developed.

9) The country should advance policy reform (including sustainable implementation of the new policy) and champion a new Nigerian Water ethic in the face of changing climate.

10) Capacities of state water management institutions should be strengthened for climate resilience approach to water resources management.

11) The management practices of state and urban water boards and basin authorities will have to be adjusted to take into account the new demands imposed by the changing climate, as part of a more holistic vision of the role of water in sustainable development processes.

12) A climate change awareness programme should be developed that could be 
rolled out at local level to provide local government officials with the necessary tools to engage with this issue and implement the strategies that are identified.

\section{Conclusions and Recommendations}

The hydrogeology of the Niger delta is dominated by the Benin Formation, which serves not only as aquifer but also facilitates recharge of groundwater in the region. Consequently, the distribution and availability of groundwater depend on the occurrence and characteristics of Benin Formation in the locality.

The progradational sedimentation pattern of the Delta not only controls to a large extent the areal and vertical distribution of the recent deposits that overlie the Benin formation, but also the structure of the aquifer systems, and explains the higher frequency and thicknesses of the clay interactions embodied within the Benin Formation as it debouches into the Atlantic Ocean. The absence or lean thickness of the quaternary sediment cover upstream ensures that recharge is more extensive at the outcrop of the Benin Formation to the north where groundwater possesses a higher hydraulichead and from where flow is driven down slope, generally in the southwards direction with an average hydraulic gradient of $3.8 \times 10^{-4}$.

Similarly, the groundwater quality closely follows the sedimentation pattern resulting in three distinct groundwater zones, namely; the northern border corresponding to the coastal plain sands with the most desirable water quality, the transitional zone mostly encircled by the meander belt with less desirable quality dominated by iron water and the coastal zone within the mangrove swamps with frequent challenges of saline intrusion. The deep salinity depths recorded by down-the-hole resistivity log in deep boreholes in Bonny and other coastal locations are evidence of groundwater quality degradation resulting from saline water intrusion into freshwater aquifers.

Analysis of the vulnerability of the various aquifers to pollution indicates that the first aquifer system in which groundwater occurs under phreatic conditions appears to be most vulnerable to pollution. This is of concern to public water supply, health management and poverty alleviation policies especially in the rural areas where there is total dependence by communities on dug wells.

The lower aquifers are less vulnerable as they enjoy some degree of protection of the intervening clay interaction embodied within the aquifer system. These deeper aquifers are considered safe and relatively free from pollution except in the coastal areas. However, there is the danger that over-pumping of groundwater could increase the already deep salinity depth thereby reducing the effective column of fresh water.

Salinity tends to increase in a southerly direction. The salinity values of groundwater in the study area appear to be generally tolerable outside the coastal zone embracing the mangrove swamp.

In any further study dedicated to this topic, a very important aspect that must be taken into account should be linked to the eustatic oscillations that have af- 
fected the iron water distribution and hydrostratigraphy of the Niger Delta region. The occurrence of offshore fresh groundwater at coastal areas, using an analytical model for estimating the extent of such occurrence should be explored. Two main drivers of such phenomenon to be identified should include: 1) the presence of entrapped paleo-freshwater during periods characterized by lower sea levels and 2) freshwater discharge from onshore aquifers to subsea aquifers under current sea level conditions.

In both cases, the onshore-offshore coastal aquifer must be conceptualized with an aquitard extending from the coastline offshore, which prevents vertical exchange between freshwater and saltwater, and a potentiometric surface which declines to the sea level offshore, far from the coastline.

Finally, it is concluded that even in worst case scenario of the impacts of climate change up to 2050, when there might be reduction of annual run off by only $20 \%$ and the recharge of approximately $25 \mathrm{BCM} / \mathrm{Yr}$ would still be in excess of consumption, implying that groundwater will continue to be sustainable..

\section{Acknowledgements}

The views expressed in this paper reflect the collective experiences of the authors gained through their research, and through interactions with colleagues. The authors may have undoubtedly failed to cite some key publications and important concepts. We take sole responsibility for all the biases, omissions, oversights, and inaccuracies.

\section{Conflicts of Interest}

The authors declare no conflicts of interest regarding the publication of this paper.

\section{References}

[1] JICA (2014) The Project for Review and Update of Nigeria National Water Resources Master Plan Vol. 2. Japan International Cooperation Agency, Yachiyo Engineering Co., Ltd., CTI Engineering International Co., Ltd., Sanyu Consultants Inc., Japan.

[2] Federal Republic of Nigeria (2013) National Water Resources Master Plan.

[3] Ngah, S. and Eze, C. (2017) Typical Hydraulic Properties of Deep Aquifers of Niger Delta from Pumping Test Data. Journal of Geoscience and Environment Protection, 5, 139-148. https://doi.org/10.4236/gep.2017.511010

[4] Etu-Efeotor, J.O. (1981) Preliminary Hydrogeochemical Investigations of Subsurface Waters in Parts of the Niger Delta. Journal of Mining and Geology, 18, 103-107.

[5] Odigi, M.I. (1989) Evaluating Groundwater Supply in Eastern Niger Delta, Nigeria. Journal of Mining and Geology, 25, 159-164.

[6] Etu-Efeotor, J.O. and Odigi, M.I. (1983) Water Supply Problems in the Eastern Niger Delta. Journal of Mining and Geology, 20, 183-193.

[7] Amadi, P.A., Ofoegbu, C.O. and Morrison, T. (1989) Hydrogeochemical Assessment of Groundwater Quality in Parts of the Niger Delta, Nigeria. Environmental 
Geology and Water Sciences, 14, 195-202. https://doi.org/10.1007/BF01705131

[8] Reyment, R.A. (1965) Aspects of the Geology of Nigeria. Ibadan Univ. Press, Ibadan.

[9] Short, K.C. and Stauble, A.J. (1967) Outline Geology of the Niger Delta. AAPG Bulletin, 54, 761-779.

[10] Merki, P. (1972) Structural Geology of the Cenozoic Niger Delta. In: Dessauvagie, T.F.J. and Whiteman, A.J., Eds., African Geology, Dept. of Geology Univ., Ibadan, 635-646.

[11] Weber, K.J. and Daukoru, E. (1975) Petroleum Geology of the Niger Delta. Jour. Min. Geol., 12, 9-12.

[12] Avbovbo, A.A. (1978) Tertiary Lithostratigraphy of Niger Delta. Bulletin of American Association of Petroleum Geology, 62, 297-306. https://doi.org/10.1306/C1EA482E-16C9-11D7-8645000102C1865D

[13] Agagu, O.K. (1979) Potential Geo Pressured Geothermal Reservoirs in the Niger Delta Subsurface. Nigerian Journal of Science, 13, 201-215.

[14] Whiteman, A. (1982) Nigeria: Its Petroleum Geology, Resources and Potential. Graham and Trotman, London, Vol. 1, 66-78.

https://doi.org/10.1007/978-94-009-7361-9

[15] Doust, H. and Omatsola, E. (1990) Niger-Delta. In: Edwards, J.D. and Santogrossi, P.A., Eds., Divergent/ Passive Margin Basins, AAPG Memoir 48, American Association of Petroleum Geologists, Tulsa, 239-248.

[16] Owolabi, O.O., Longjohn, T.F. and Ajienka, J.A. (1990) An Empirical Expression for Permeability in Unconsolidated Sands of Eastern Niger Delta. Journal of Petroleum Geology, 17, 111-116. https://doi.org/10.1111/j.1747-5457.1994.tb00117.x

[17] Koledoye, B.A., Aydin, A. and May, E. (2003) A New Processed-Based Methodology for Analysis of Shale Smear along Normal Faults in the Niger Delta. AAPG Bulletin, 87, 445-463. https://doi.org/10.1306/08010200131

[18] Reijers, T.J.A. (2011) Stratigraphy and Sedimentology of the Niger Delta. Geologos, 17, 133-162. https://doi.org/10.2478/v10118-011-0008-3

[19] Murat, R.C. (1970) Stratigraphy and Paleogeography of the Cretaceous and Lower Tertiary in Southern Nigeria. In: Dessauvagie, T.T.J. and Whiteman, A.J., Eds., AfrGeol, University of Ibadan Press, Ibadan, 251-266.

[20] Amajor, L.C. (1991) Aquifers in the Benin Formation (Miocene Recent), Eastern Niger Delta, Nigeria: Lithostratigraphy, Hydraulics, and Water Quality. Environmental Geology and Water Sciences, 17, 851-860. https://doi.org/10.1007/BF01701565

[21] Nwankwoala, H.O. and Ngah, S.A. (2014) Groundwater Resources of the Niger Delta: Quality Implications and Management Considerations. International Journal of Water Resources and Environmental Engineering, 6, 155-163. https://doi.org/10.5897/IJWREE2014.0500

[22] Amajor, L.C. (1989) Geological Appraisal of Groundwater Exploitations in the Eastern Niger Delta. In: Ofoegbu, C.O., Ed., Groundwater and Mineral Resources of Nigeria, Braunschweig/Weisbaden, Friedr Vieweg and Sohn, 85-100. https://doi.org/10.1007/978-3-322-87857-1 8

[23] Etu-Efeotor, J.O. and Akpokodje, E.G. (1990) Aquifer Systems of the Niger Delta. Journal of Mining and Geology, 26, 279-285.

[24] Akpokodje, E.G., Etu-Efeotor, J.O. and Mbeledogu, I.U. (1996) A Study of Environmental Effects of Deep Subsurface Injection of Drilling Waste on Water Re- 
sources of the Niger Delta. CORDEC, University of Port Harcourt, Port Harcourt.

[25] Ngah, S.A. and Nwankwoala, H.O. (2013) Assessment of Static Water Level Dynamics in Parts of the Eastern Niger Delta. The International Journal of Engineering and Science, 2, 136-141.

[26] Akpoborie, I.A. (2011) Aspects of the Hydrology of the Western Niger Delta Wetlands: Groundwater Conditions in the Neogene (Recent) Deposits of the Ndokwa Area. Proceedings of the Environmental Management Conference, Federal University of Agriculture, Abeokuta, $13 \mathrm{p}$.

[27] Allen, J.R.L. (1970) Sediments of the Modern Niger Delta: A Summary and Review. In: Morgan, J.P., Ed., Deltaic Sedimentation: Modern and Ancient, Society of Economic Paleontologists and Mineralogists, Tulsa, Vol. 15, 138-151. https://doi.org/10.2110/pec.70.11.0138

[28] Asseez, L.O. (1975) Review of the Stratigraphy, Sedimentation and Structure of the Niger Delta. In: Kogbe, C.A., Ed., Geology of Nigeria, Rockview, Jos, 311-334.

[29] Ngah, S.A. (2009) Deep Aquifer Systems of Eastern Niger Delta: Their Hydrogeological Properties, Groundwater Chemistry and Vulnerability to Degradation. Unpublished PhD Thesis, Rivers State University of Science and Technology, Port Harcourt, 247.

[30] Krishna, R. (1970) Hydrmeteorological Aspects of Estimating Groundwater Potential. Seminar on Groundwater Potentials in Hard Rock Areas, Vol. 1, 1-18.

[31] Chaturvedi, R.S. (1973) A Note on the Investigation of Groundwater Resources of Uttar Pradesh. Annual Report U.P. Irrigation Research Institute, India.

[32] Abam, T.K.S. (2016) Engineering Geology of the Niger Delta. Journal of Earth Sciences and Geotechnical Engineering, 6, 65-89.

[33] Dickey, P., George, G.O. and Barker, C. (1987) Relationships among Oils and Water Compositions in the Niger Delta. American Association Petroleum Geology Bulletin, 71, 1319-1328. https://doi.org/10.1306/703C806A-1707-11D7-8645000102C1865D

[34] Amajor, L.C. and Gbadebo, A.M. (1992) Oil Field Brines of Meteoric and Connate origin in the Eastern Niger Delta. Journal of Petroleum Geology, 15, 481-488. https://doi.org/10.1111/j.1747-5457.1992.tb01047.x

[35] Groundscan (2002) Report of Sand Search on the Niger River near NAOC IPP at Okpai, Kwale Delta State (35 Pages) June 2002.

[36] Ngah, S.A. (1990) Groundwater Resource Development in the Niger Delta: Problems and Prospects. Proceedings of the 6th International Congress of the International Association of Engineering Geology, Amsterdam, 80-94.

[37] Offodile, M.E. (2002) Groundwater Study and Development in Nigeria. 2nd Edition, Mecon Geology and Engineering Services Ltd., Jos, 453 p.

[38] Nwankwoala, H.O. (2005) Estimating Aquifer Parameters in Port Harcourt and Environs Using Pumping Test Data. M.Phil Thesis, Rivers State University of Science and Technology, Port Harcourt, 104 p.

[39] Nwankwoala, H.O., Abam, T.K.S., Ede, P.N., Teme, S.C. and Udom, G.J. (2008) Estimates of Aquifer Hydraulic Properties Using Pumping Test Data: A Case Study of Port Harcourt and Environs. Water Resources Journal of the Nigerian Association of Hydrogeologists, 18, 25-31.

[40] United Nations Environmental Programme (UNEP) (2002) United Nations Environment Programme 2002 Annual Report. http://www.unep.org

[41] Allen, J.R.L. (1965) Late Quaternary Niger Delta and Adjacent Areas: Sedimentary 
Environments and Lithofacies. Bulletin American Association of Petroleum Geology, 49, 547-600. https://doi.org/10.1306/A663363A-16C0-11D7-8645000102C1865D

[42] Oomkens, E. (1974) Lithofacies Relations in the Late Quaternary Niger Delta Complex. Sedimentology, 21, 195-222. https://doi.org/10.1111/j.1365-3091.1974.tb02056.x

[43] Edwards, K.A., Classen, G.A. and Schroten, E.H.J. (1983) The Water Resource in Tropical Africa and Its Exploitation. E-Book Series. ILCA Publications, 103 p.

[44] Abam, T.K.S. (1999) Dynamics and Quality of Water Resources in the Niger Delta. Proc. of IUGG Symposia HS5, IAHS Publ. 259, 429-437.

[45] Earman, E. and Dettinger, M. (2011) Potential Impacts of Climate Change on Groundwater Resources-A Global Review. Journal of Water and Climate Change, 2, 213-229. https://doi.org/10.2166/wcc.2011.034

[46] Alley, W.M. (2001) Groundwater and Climate Change. Groundwater, 39, 161-169. https://doi.org/10.1111/j.1745-6584.2001.tb02295.x

[47] Dragoni, W. and Sukhija, B.S. (2008) Climate Change and Groundwater-A Short Review. In: Dragoni, W. and Sikhija, B.S., Eds., Climate Change and Groundwater, Geological Society, London, Special Publications 288, 1-12. https://doi.org/10.1144/SP288.1

[48] Hem, J.D. (1992) Study and Interpretation of the Chemical Characteristics of Natural Water. 3rd Edition, US Geological Survey Water-Supply Paper 2254, Washington DC.

[49] Kayane, I. (1997) Global Warming and Groundwater Resources in Arid Lands. In: J. Uitto, I. and Schneider, J., Eds., Freshwater Resources in Arid Lands. UNU Global Environmental Forum $V$, United Nations University Press, Tokyo, 70-80.

[50] Rahmstorf, S. (2007) A Semi-Empirical Approach to Projecting Future Sea-Level Rise. Science, 315, 368-370. https://doi.org/10.1126/science.1135456

[51] Sherif, M.M. and Singh, V.P. (1999) Effect of Climate Change on Sea Water Intrusion in Coastal Aquifers. Hydrologic Processes, 13, 1277-1287. https://doi.org/10.1002/(SICI)1099-1085(19990615)13:8<1277::AID-HYP765>3.0.C O;2-W

[52] Awosika, L.F., French, G.T., Nicholls, R.J. and Ibe, C.E. (1992) The Impact of Sea Level Rise on the Coastline of Nigeria. Proceedings of IPCC Symposium on the Rising Challenges of the Sea, Magaritta, 14-19 March 1992, $10 \mathrm{p}$.

[53] IPCC (2007) Climate Change 2007: Impacts, Adaptation, and Vulnerability. Contribution of Working Group II to the Fourth Assessment Report of the Intergovernmental Panel on Climate Change. Cambridge University Press, Cambridge.

[54] Oude Essink, G.H.P., Van Baaren E.S. and De Louw, P.G.B. (2010) Effects of Climate Change on Coastal Groundwater Systems: A Modelling Study in the Netherlands. Water Resources Research, 46, W00F04.

https://doi.org/10.1029/2009WR008719

[55] Jiménez Cisneros, B.E., Oki, T., Arnell, N.W., Benito, W., Cogley, J.G., Döll, P., Jiang, T. and Mwakalila, S.S. (2014) Freshwater Resources. In: Field, C.B., Barros, V.R., Dokken, D.J., Mach, K.J., Mastrandrea, M.D., Bilir, T.E., Chatterjee, M., Ebi, K.L., Estrada, Y.O., Genova, R.C., Girma, B., Kissel, E.S., Levy, A.N., MacCracken, S., Mastrandrea, P.R. and White, L.L., Eds., Climate Change 2014: Impacts, Adaptation, and Vulnerability, Part A: Global and Sectoral Aspects. Contribution of Working Group II to the Fifth Assessment Report of the Intergovernmental Panel on Climate Change, Cambridge University Press, Cambridge, New York, 229-269. 
[56] Vandenbohede, A., Luyten, K. and Lebbe, L. (2008) Effects of Global Change on Heterogeneous Coastal Aquifers: A Case Study in Belgium. Journal of Coastal Resources, 24, 160-170. https://doi.org/10.2112/05-0447.1 
Appendix 1: Location of Boreholes with Strata Logs, Their Depths and Static Water Level in Parts of Niger Delta (Ngah and Nwankwoala, 2013)

\begin{tabular}{|c|c|c|c|c|}
\hline S/NO. & Borehole location & Geomorphic zone & Total depth drilled (m) & Static water level (m) \\
\hline 1 & Ogbo & CPS & 186 & 7.0 \\
\hline 2 & Edocha & CPS & 185 & 4.26 \\
\hline 3 & Port Harcourt (Old GRA) & CPS & 207 & 5.5 \\
\hline 4 & Ndoni & CPS & 182 & 7.55 \\
\hline 5 & Idu & CPS & 185 & 6.2 \\
\hline 6 & Ebubu & CPS & 92 & 6.0 \\
\hline 7 & Azikoro & FWS & 335 & 8.6 \\
\hline 8 & Swali & FWS & 335 & 8.8 \\
\hline 9 & Finima (Life camp) & CBR & 360 & 1.3 \\
\hline 10 & Onne $(\mathrm{FOT})^{\star}$ & CPS & 190 & 6.0 \\
\hline 11 & Finima (BRT) & CBR & 360 & 1.0 \\
\hline 12 & Bassambiri & CBR & 250 & 0.8 \\
\hline 13 & Atubo & SWS & 193 & 1.37 \\
\hline 14 & Nembe & SWS & 195 & 2.1 \\
\hline 15 & Ogbia & FWS & 198 & 2.5 \\
\hline 16 & Brass & CBR & 192 & 0.69 \\
\hline 17 & Twon Brass & CBR & 260 & 1.2 \\
\hline 18 & Brass (NAOC Tank farm) & CBR & 256 & 0.8 \\
\hline 19 & Otegila & FWS & 185 & 4.0 \\
\hline 20 & Okoroba & FWS & 225 & 0.0 \\
\hline 21 & Amakalakala & FWS & 160 & 9.14 \\
\hline 22 & Otugidi & FWS & 426 & 0.91 \\
\hline 23 & Otuesaga & FWS & 102 & 12.19 \\
\hline 24 & Owaza & CPS & 152 & 3.6 \\
\hline 25 & Kolo creek & FWS & 102 & 5.2 \\
\hline 26 & Onne (NAFCON) & CPS & 264 & 7.49 \\
\hline 27 & Otakeme & FWS & 300 & 4.2 \\
\hline 28 & Omoku & SWP & 183 & 0.68 \\
\hline 29 & Aleto Eleme & CPS & 150 & 7.75 \\
\hline 30 & Bukuma & SWS & 183 & 1.25 \\
\hline 31 & Kala Degema & SWS & 171 & 2.8 \\
\hline 32 & Abissa & SWS & 147 & 0.4 \\
\hline 33 & Bille & sws & 193 & 0.6 \\
\hline 34 & Opiro & SWS & 138 & 13 \\
\hline 35 & Rumonye & CPS & 188 & 22 \\
\hline 36 & Chokocho & CPS & 132 & 10 \\
\hline 37 & Egwi & CPS & 201 & 8.25 \\
\hline 38 & Umuechem & CPS & 132 & 5.5 \\
\hline 39 & Okrika & SWS & 113 & 11.4 \\
\hline 40 & Ibuluya-Dikibo & SWS & 180 & 8.2 \\
\hline 41 & Bolo 1 & SWS & 92 & 5.5 \\
\hline 42 & Abam Ama & SWS & 128 & ARTESIAN \\
\hline 43 & Okujiagu & SWS & 110 & 0.7 \\
\hline 44 & George Ama & SWs & 200 & 0.9 \\
\hline
\end{tabular}


Continued

\begin{tabular}{lcccc}
\hline 45 & Kalaibiama & CBR & 305 & 2.4 \\
46 & Bonny & CBR & 198 & 3.0 \\
47 & Bonny (Water Board) & CBR & 450 & 1.2 \\
48 & Bonny (Oguede) & CBR & 460 & ARTESIAN \\
49 & Okoloma (Afam) & CPS & 120 & 6.3 \\
50 & Borokiri* & SWS & 190 & 2.5 \\
51 & Gbaran-Ubie & FWS & 530 & - \\
52 & Ogidigben/Ugorodo & CBR & 600 & - \\
\hline
\end{tabular}

$\mathrm{CPS}=$ coastal plain sands, FWS $=$ freshwater swamp, SWS $=$ saltwater swamp, $\mathrm{CBR}=$ coastal beaches and ridges, $\mathrm{SWP}=$ sombreiro warri deltaic plain,${ }^{*}=$ transitional zone

\section{Appendix 2: Partial Groundwater Quality Data in Parts of the Eastern Niger Delta}

\begin{tabular}{|c|c|c|c|c|c|c|c|c|c|c|}
\hline S/No. & Location & Zone/Aquifer & $\begin{array}{l}\text { Depth } \\
(\mathrm{m})\end{array}$ & $\begin{array}{l}\text { Iron } \\
(\mathrm{mg} / \mathrm{l})\end{array}$ & $\begin{array}{l}\text { Chloride } \\
(\mathrm{mg} / \mathrm{l})\end{array}$ & $\begin{array}{l}\text { Salinity } \\
(\mathrm{mg} / \mathrm{l})\end{array}$ & $\begin{array}{l}\text { Conductivity } \\
\text { (us } / \mathrm{cm})\end{array}$ & $\mathrm{pH}$ & $\begin{array}{l}\text { Alkalinity } \\
(\mathrm{mg} / \mathrm{l})\end{array}$ & $\begin{array}{c}\text { Hardness } \\
(\mathrm{mg} / \mathrm{l})\end{array}$ \\
\hline 1 & Kanana & SWS & 186 & 0 & 34 & 500 & 125 & 6.7 & 0.12 & 38 \\
\hline 2 & Kala Degema & $"$ & 40.96 & 0 & 18 & 150 & - & 7.3 & 0.38 & 6 \\
\hline 3 & Krakrama & $"$ & 75 & 2.5 & 48 & 700 & 100 & 6.8 & - & 16 \\
\hline 4 & Abalama & $"$ & 60.96 & 2 & 36 & 10.74 & 35 & 6.7 & 30 & 11 \\
\hline 5 & Buguma & $"$ & 60.96 & 0 & 10.64 & 17.55 & - & 6.2 & 6.5 & 17 \\
\hline 6 & Okrika MLand & $"$ & 320 & 0 & 35.5 & 58.5 & 19 & 6.2 & 10.4 & 20 \\
\hline 7 & Ibuluya-Dikibo & $"$ & 180 & 0 & 32 & 18 & 20 & 4.5 & 10 & 21 \\
\hline 8 & Bolo I & $"$ & 91.44 & 0 & 99 & 14 & 16 & 7 & 0.12 & 31 \\
\hline 9 & Bolo II & $"$ & 91.44 & 0 & 97 & 16 & 40 & 6.8 & 0.1 & 35 \\
\hline 10 & Kalio-Ama & $"$ & 82.88 & 0.5 & 10 & 331 & 58 & 6.4 & 0.1 & 61 \\
\hline 11 & Abam-Ama & $"$ & 128.02 & 0 & 6.38 & 100 & 23 & 5.9 & 21 & Artesian \\
\hline 12 & Okujagu & $"$ & 30 & 0.8 & 62 & 100 & - & 4.5 & 2 & 30 \\
\hline 13 & George-Ama & $"$ & 109.73 & 1.8 & 31.5 & 60.25 & 29 & 5.1 & - & 22 \\
\hline 14 & Isiokpo & CPS & 70.1 & 2 & 38.94 & 64.4 & 20 & 5.6 & 15 & 10 \\
\hline 15 & Aluu & $"$ & 60.96 & 0.2 & 10 & 50 & 23 & 6.1 & 2 & 6 \\
\hline 16 & Umuoji & $"$ & 81 & 10 & 32 & 80 & - & 8.2 & - & 68 \\
\hline 17 & Ogbakiri & $"$ & 78.03 & 0.01 & 24.2 & 51.9 & 4.5 & 6.2 & 0.5 & 60 \\
\hline 18 & Ndele & $"$ & 72.5 & 0 & 10.6 & 100 & 13.5 & 7.5 & 19 & 9 \\
\hline 19 & Omerelu & $"$ & 70.1 & 0.4 & 20 & 20 & 20 & 6.5 & 0.6 & 8 \\
\hline 20 & Ubima & $"$ & 70.1 & 0 & 18 & 50 & 18 & 5.2 & 2 & 4 \\
\hline 21 & Elele & CPS & 60.96 & 0 & 29.8 & 49 & 15 & 6 & 3 & 5 \\
\hline 22 & Ibaa & $"$ & 60.96 & 0 & 40 & 68.25 & 12 & 6.2 & - & 2 \\
\hline 23 & Obelle & $"$ & 81 & 0 & 48 & 63 & 6.7 & 6.1 & - & 0 \\
\hline 24 & Rumuewho & $"$ & 54.86 & 0.3 & 10 & 50 & - & 6.2 & - & 38 \\
\hline 25 & Egwi & $"$ & 61.28 & 0.15 & 3.4 & 65 & - & 6.5 & - & 28 \\
\hline
\end{tabular}




\section{Continued}

\begin{tabular}{|c|c|c|c|c|c|c|c|c|c|c|}
\hline 26 & Rumuoyo & $"$ & 57.3 & 0.3 & 24 & 73 & - & 6.4 & - & 8 \\
\hline 27 & Ulakwo & $"$ & 67.06 & 0 & 13 & 60.2 & 100 & 7.4 & - & 34 \\
\hline 28 & Opiro & $"$ & 138 & 0 & 16 & 100 & 12.5 & 6.2 & 6 & 10 \\
\hline 29 & Rumuokochi & $"$ & 91 & 10 & 12 & 60 & 100 & 6.2 & - & 20 \\
\hline 30 & Umuechem & $"$ & 132 & 0.3 & 11 & 100 & 36 & 6.7 & 3 & 6 \\
\hline 31 & Kalibiama & CBR & 281 & 0 & 10 & 202 & 440 & 8.4 & - & 488 \\
\hline 32 & Bonny & $"$ & 304 & 0.8 & 5 & 186 & 140 & 5.9 & - & 78 \\
\hline 33 & Oloma I & $"$ & 91.46 & 0.8 & 810 & 210 & 600 & 6.5 & 90 & 72 \\
\hline 34 & Oloma II & $"$ & 82.88 & 0 & 250 & 220 & 380 & 6.2 & 20 & 454 \\
\hline 35 & Illoma Opobo & $"$ & 19.8 & 0.6 & 330 & 60 & 280 & 7.2 & - & 84 \\
\hline 36 & Gbokokiri & $"$ & 176.8 & 0.4 & 300 & 192 & - & 6.6 & - & 18 \\
\hline 37 & Ikuru & $"$ & 190 & 0.38 & 351 & 242 & - & 6.7 & - & 70 \\
\hline 38 & G.R.A. P.H. & “ & 170 & 0 & 26 & 50 & 7 & 5.3 & 2 & 6 \\
\hline 39 & Creek Road & $"$ & 170 & 0.02 & 390.5 & 643.5 & 150 & 5.8 & 35 & 135 \\
\hline 40 & Potts Johnson & $"$ & 180 & 0.02 & 401 & 661 & 160 & 5.8 & 18 & 135 \\
\hline 41 & Onne & Lower & 264 & 0.25 & 7 & & 19 & 6.2 & & 2.5 \\
\hline 42 & Bodo & Upper & 80.56 & 0.25 & 4.5 & & $\mathrm{n} / \mathrm{d}$ & 6.5 & & 18 \\
\hline 43 & Baen & Upper & 60.96 & 0.1 & 24.1 & & $\mathrm{n} / \mathrm{d}$ & 6.2 & & 12 \\
\hline 44 & Lubara & Upper & 60.9 & 0.1 & 22 & & 90 & 6.1 & & 45 \\
\hline 45 & Opuoko & Upper & 60.9 & 0.1 & 16 & & 95 & 7.1 & & 44 \\
\hline 46 & Kono & Upper & 60.9 & 0.2 & 18 & & 55 & 6.6 & & 8 \\
\hline 47 & Beeri & Upper & 60.9 & 0 & 28 & & $\mathrm{n} / \mathrm{d}$ & 7.3 & & 18 \\
\hline 48 & Ahoada & Upper & 65.5 & 0.04 & 21 & & $\mathrm{n} / \mathrm{d}$ & 5.6 & & 8 \\
\hline 49 & Joinkrama & Upper & 76.22 & 6.2 & 5.6 & & 400 & 6.3 & & 13.3 \\
\hline 50 & Bassambri & Lower & 250 & 0.02 & 3 & & 99 & 7.5 & & 14.5 \\
\hline 51 & Ogbia & Upper & 66.96 & 4 & 109 & & 367.5 & 6.9 & & 9.5 \\
\hline 52 & Abua & Upper & 60.96 & 0.02 & 26 & & 1500 & 6 & & 25 \\
\hline 53 & Abonnema & Upper & 9.24 & 0 & 53.4 & & 100 & 6.9 & & 9 \\
\hline 54 & Okirika mainland & Lower & 320 & 0.2 & 35.5 & & 19 & 6.2 & & 20 \\
\hline 55 & Isiokpo & Upper & 70.1 & 2 & 38.94 & & 20 & 5.6 & & 10 \\
\hline 56 & Elele & Upper & 60.96 & 0 & 29.8 & & 15 & 6 & & 5 \\
\hline 57 & Moscow Rd PHC & Lower & 250 & 0.04 & 63.9 & & 300 & 5.4 & & 13 \\
\hline 58 & Egwi & Upper & 61.28 & 0.15 & 3.4 & & $\mathrm{n} / \mathrm{d}$ & 6.5 & & 28 \\
\hline 59 & Yenegoa & Upper & 85.4 & 4.5 & 48.4 & & 172.9 & 6.3 & & 8 \\
\hline 60 & Bonny & Lower & 304 & 5 & 5 & & 140 & 5.9 & & 78 \\
\hline
\end{tabular}

$\mathrm{CPS}=$ coastal plain sands, FWS $=$ freshwater swamp, SWS $=$ saltwater swamp, $\mathrm{CBR}=$ coastal beaches and ridges, $\mathrm{SWP}=$ Sombreiro-Warri deltaic plain. 
Appendix 3: Salinity of Groundwater at Different Locations and Depths in the Niger Delta (After Ngah and Nwankwoala 2013)

\begin{tabular}{|c|c|c|c|c|}
\hline S/No. & Borehole Locations & Geomorphic Zones & Depth (m) & Salinity (mg/l) \\
\hline 1. & Ahoada & CPS & 65.53 & 35.0 \\
\hline 2. & Ogbo & $"$ & 186 & 40.0 \\
\hline 3. & Edeocha & $"$ & 185 & 150.0 \\
\hline 4. & Udiereke-Ubie & $"$ & 76.20 & 5.7 \\
\hline 5. & Abua & $"$ & 60.96 & 43.0 \\
\hline 6. & Joinkrama & $"$ & 176.22 & 136.6 \\
\hline 7. & Ndoni & $"$ & 382 & 241.0 \\
\hline 8. & Ebubu & $"$ & 91.44 & 60 \\
\hline 9. & Mbiama & FWS & 175 & 48.9 \\
\hline 10. & Obibi & $"$ & 76.22 & 50.0 \\
\hline 11. & Zarama & SWS & 89 & 149.1 \\
\hline 12. & Bassambiri & $"$ & 250 & 500.0 \\
\hline 13. & Atubo & $"$ & 193 & 872.0 \\
\hline 14. & Nembe & $"$ & 193 & 21.0 \\
\hline 15. & Ogbia & FWS & 101 & 180.0 \\
\hline 16. & Brass & CBR & 192 & 116.0 \\
\hline 17. & Emerego & $"$ & 78 & 169.6 \\
\hline 18. & Kolo & $"$ & 101.59 & 425.4 \\
\hline 19. & Amakalakala & FWS & 160.96 & 98.6 \\
\hline 20. & Sangana & $"$ & 60.96 & 50.0 \\
\hline 21. & Oruma & FWS & 101.59 & 50.0 \\
\hline 22. & Onne & CPS & 264 & 210.0 \\
\hline 23. & Bien Gwara & $"$ & 60.96 & 6.8 \\
\hline 24. & Bodo & " & 80.56 & 210.0 \\
\hline 25. & Baen & $"$ & 60.96 & 27.9 \\
\hline 26. & Kongho & $"$ & 60.96 & 240.7 \\
\hline 27. & Lubara & $"$ & 60.96 & 60.25 \\
\hline 28. & Baun & $"$ & 60.96 & 60 \\
\hline 29. & Opuoko & $"$ & 60.96 & 60.25 \\
\hline 30. & Kono & $"$ & 60.96 & 450 \\
\hline 31. & Kanni & $"$ & 60.96 & 60 \\
\hline 32. & Beeri & $"$ & 60.96 & 62 \\
\hline 33. & Sii Babbe & $"$ & 60.96 & 72 \\
\hline 34. & Soku & sws & 95.0 & 50 \\
\hline
\end{tabular}




\section{Continued}

\begin{tabular}{|c|c|c|c|c|}
\hline 35. & Tombia & $"$ & 59.44 & 60 \\
\hline 36. & Idama & $"$ & 100 & 25.00 \\
\hline 37. & Abonnema & $"$ & 9.24 & 15.60 \\
\hline 38. & Harry's Town & $"$ & 95 & 150 \\
\hline 39. & Kula & $"$ & 183.0 & 113 \\
\hline 40. & Bukuma & $"$ & 60.96 & 210 \\
\hline 41. & Kanana & SWS & 186 & 500 \\
\hline 42. & Kala Degema & $"$ & 40.96 & 150.0 \\
\hline 43. & Krakrama & $"$ & 75 & 700 \\
\hline 44. & Abalama & $"$ & 60.96 & 10.74 \\
\hline 45. & Buguma & $"$ & 60.96 & 17.55 \\
\hline 46. & Okrika Mainland & $"$ & 320 & 58.5 \\
\hline 47. & Ibuluya-Dikibo & $"$ & 180 & 18.00 \\
\hline 48. & Bolo I & $"$ & 91.44 & 14.00 \\
\hline 49. & Bolo II & $"$ & 91.44 & 16.00 \\
\hline 50. & Kalio-Ama & $"$ & 82.88 & 331 \\
\hline 51. & Abam-Ama & $"$ & 128.02 & 100 \\
\hline 52. & Okujagu & $"$ & 30.0 & 100 \\
\hline 53. & George-Ama & $"$ & 109.73 & 60.25 \\
\hline 54. & Isiokpo & CPS & 70.1 & 64.4 \\
\hline 55. & Aluu & $"$ & 60.96 & 50 \\
\hline 56. & Umuoji & $"$ & 81 & 80 \\
\hline 57. & Ogbakiri & $"$ & 78.03 & 51.9 \\
\hline 58. & Ndele & $"$ & 72.5 & 100 \\
\hline 59. & Omerelu & $"$ & 70.1 & 20 \\
\hline 60. & Ubima & $"$ & 70.1 & 50 \\
\hline 61. & Elele & CPS & 60.96 & 49 \\
\hline 62. & Ibaa & $"$ & 60.96 & 68.25 \\
\hline 63. & Obelle & $"$ & 81.0 & 63 \\
\hline 64. & Rumuewho & $"$ & 54.86 & 50 \\
\hline 65. & Egwi & $"$ & 61.28 & 65 \\
\hline 66. & Rumuoyo & $"$ & 57.3 & 73 \\
\hline 67. & Ulakwo & $"$ & 67.06 & 60.2 \\
\hline 68. & Opiro & $"$ & 138 & 100 \\
\hline 69. & Rumuokochi & $"$ & 91 & 60 \\
\hline 70. & Umuechem & $"$ & 132 & 100 \\
\hline 71. & Kalibiama & $\mathrm{CBR}$ & 281 & 202.0 \\
\hline 72. & Bonny & $"$ & 304 & 186 \\
\hline 73. & Oloma I & $"$ & 91.46 & 210.0 \\
\hline 74. & Oloma II & $"$ & 82.88 & 220.0 \\
\hline
\end{tabular}




\section{Continued}

\begin{tabular}{|c|c|c|c|c|}
\hline 75. & Illoma Opobo & $"$ & 19.8 & 60 \\
\hline 76. & Gbokokiri & $"$ & 176.8 & 192.0 \\
\hline 77. & Ikuru & $"$ & 190 & 242.0 \\
\hline 78. & G.R.A.P.H. & “ & 170 & 50 \\
\hline 79. & Creek Road & $"$ & 170.0 & 643.5 \\
\hline 80. & Potts Johnson & $"$ & 180.0 & 661 \\
\hline 81. & NDBDA & CPS & 170 & 26.4 \\
\hline 82. & Borokiri & $"$ & 176.8 & 63.7 \\
\hline 83. & Govt. House, PH & $"$ & 110 & 24 \\
\hline 84. & Moscow Road & $"$ & 180 & 95.3 \\
\hline 85. & Central Police Stn & $"$ & 176.8 & \\
\hline 86. & Choba & $"$ & 140 & 672.75 \\
\hline 87. & Rumuomasi & $"$ & 131.0 & 60.25 \\
\hline 88. & Rumuokoro & $"$ & 152.0 & 100 \\
\hline 89. & Rumuodamaya & $"$ & 168.0 & 17.55 \\
\hline 90. & Elelenwo & $"$ & 171.8 & 19.82 \\
\hline 91. & Iriebe & $"$ & 163.0 & 60.0 \\
\hline 92. & Aagbere Odoni & FWS & 76.2 & 50 \\
\hline 93. & Peretorugbene & $"$ & 211.0 & 180 \\
\hline 94. & Ekeremor & $"$ & 202 & 30 \\
\hline 95. & Toru Ndoro & $"$ & 211 & 150 \\
\hline 96. & Torofani & $"$ & 165 & 30 \\
\hline 97. & Ofoni & $"$ & 186 & 150 \\
\hline 98. & Toro Anjiama & $"$ & 215 & 105 \\
\hline 99. & Forupa & $"$ & 215 & 50 \\
\hline 100. & Asamabiri & $"$ & 81.0 & 60 \\
\hline 101. & Amarata & FWS & 180 & 50 \\
\hline 102. & Ukubie & $"$ & 85.3 & 82 \\
\hline 103. & Tebidaba & $"$ & 171.0 & 240 \\
\hline 104. & Aguobiri & $"$ & 79 & 355 \\
\hline 105. & Okolobiri & $"$ & 75 & 511 \\
\hline 106. & Amassoma & $"$ & 180 & 30.4 \\
\hline 107. & Agudama-Epie & $"$ & 242.67 & 181.4 \\
\hline 108. & Oporoma & $"$ & 42.7 & 163.4 \\
\hline 109. & Peremabiri & $"$ & 300 & 116 \\
\hline 110. & Amatolo & $"$ & 161.0 & 50 \\
\hline 111. & Yenagoa & $"$ & 185.34 & 85.9 \\
\hline 112. & Oyorokoto & $"$ & - & 49.3 \\
\hline
\end{tabular}

CPS $=$ Coastal Plain Sands, FWS $=$ Freshwater Swamp, SWS $=$ Saltwater Swamp, CBR $=$ Coastal Beaches and Ridges. 